\title{
RETIREMENT, EARLY RETIREMENT AND DISABILITY: EXPLAINING LABOR FORCE PARTICIPATION AFTER 55 IN FRANCE
}

\author{
Luc Behaghel \\ Didier Blanchet \\ Muriel Roger \\ Working Paper 20030 \\ http://www.nber.org/papers/w20030 \\ NATIONAL BUREAU OF ECONOMIC RESEARCH \\ 1050 Massachusetts Avenue \\ Cambridge, MA 02138 \\ April 2014
}

This paper presents the views of the authors and should not be interpreted as reflecting the views of the Banque de France, INSEE, or the National Bureau of Economic Research.

NBER working papers are circulated for discussion and comment purposes. They have not been peerreviewed or been subject to the review by the NBER Board of Directors that accompanies official NBER publications.

(C) 2014 by Luc Behaghel, Didier Blanchet, and Muriel Roger. All rights reserved. Short sections of text, not to exceed two paragraphs, may be quoted without explicit permission provided that full credit, including $(\mathcal{C}$ notice, is given to the source. 
Retirement, Early Retirement and Disability: Explaining Labor Force Participation after 55

in France

Luc Behaghel, Didier Blanchet, and Muriel Roger

NBER Working Paper No. 20030

April 2014

JEL No. H55,J14,J26

\begin{abstract}
$\underline{\text { ABSTRACT }}$
We analyze the influence of health and financial incentives on the retirement behavior of older workers in France, building upon Stock and Wise (1990) option value approach. The model accounts for three main retirement routes: the normal retirement, disability insurance (DI) and unemployment/preretirement pathways, and is estimated with a combination of microeconomic datasets that include the French data of the European SHARE survey.

The estimates confirm that a decrease in the generosity of the pension and DI schemes induces people to stay longer in the labor market, and that people with better health tend to retire later. We present extreme situations simulating what individual's retirement behavior would have been if only one retirement route had existed and in the absence of constraints on work capabilities. We show that average years of work between 55 and 64 are nearly 14\% greater when regular retirement incentives are applied to the whole population than when it is DI rules that are systematically applied.
\end{abstract}

Luc Behaghel

Paris School of Economics - Inra

48 boulevard Jourdan

75014 PARIS

FRANCE

luc.behaghel@ens.fr

Didier Blanchet

INSEE- CREST

15 Blvd. Gabriel Péri BP 100

92244 Makakoff Cedex FRANCE

didier.blanchet@insee.fr
Muriel Roger

Banque de France

Paris School of Economics - Inra

46-2401 DGEI-DEMS-SAMIC

Banque de France

31 rue Croix des Petits Champs

75001 Paris

France

muriel.roger@ens.fr 


\title{
RETIREMENT, EARLY RETIREMENT AND DISABILITY: EXPLAINING LABOR FORCE PARTICIPATION AFTER 55 IN FRANCE
}

\author{
L. Behaghel ${ }^{1}$ D. Blanchet ${ }^{2}$ and M. Roger ${ }^{34}$
}

(November 2013)

\section{Introduction}

The link between health status and retirement has long been neglected in the French pension debate. The French system offers early retirement possibilities to people suffering from handicap or invalidity, but they never had the importance they have taken in some other countries. The reason is twofold: (a) an age at normal retirement that used to be low compared to international standards, and (b) the preeminence of two other pathways, unemployment insurance and public preretirement schemes, for exits at still lower ages. A large fraction of people wishing to retire early because of poor health conditions could do so without explicitly invoking this factor. It is at the most in ex post selfassessments of retirement motives that health considerations seemed to play a significant role (see Barnay and Jeger, 2006) but with the well-known difficulty of correcting such assessments from justification biases.

This situation has started evolving over the last decade. Four reforms have been conducted that have or will strongly reduce possibilities to leave as early as 60, and specifically in 2010 that has shifted the minimum age to 62 , with only limited derogations for earlier exits. Simultaneously, access to public early-retirement schemes has been dramatically reduced: except for some very specific categories of workers, these schemes are currently under extinction. Some tightening of rules also took place within the unemployment route: until recently, recipients of unemployment allowances aged more than a certain age were exempted from seeking employment, making their condition very close to the one of pre- or fully retired workers. This exemption has been abolished in 2012 .

\footnotetext{
${ }^{1}$ Paris School of Economics -Inra ${ }^{2}$ INSEE- CREST

${ }^{3}$ Banque de France, Paris School of Economics -Inra, INSEE D2E

${ }^{4}$ This paper presents the views of the authors and should not be interpreted as reflecting the views of the Banque de France or INSEE.
} 
All these changes have started producing significant results in terms of employment or labor force participation rates in the 55-64 age group (see Figure 1). In this context, interest for the health/retirement connection has now emerged as a much more central issue. This issue can be considered from two opposite point of views.

\section{(Insert figure1)}

- From the point of view of those who seek to maximize the impact of past reforms on actual retirement ages, one potential preoccupation is the risk of seeing the invalidity route to retirement progressively expand as an alternative to those other routes that are progressively shut down or made much less attractive. This substitution effect is well-known: reducing opportunities offered by one route or a subset of existing routes generally leads to a redirection of flows towards other pathways, limiting the ex post efficiency of the initial policy.

- From the opposite point of view of individual well-being, one can conversely argue that bad health is a legitimate motive for benefiting of an early exit and that it should be more systematically taken into account in the design of retirement policies.

The second issue is closely related to two other ones: (a) the question of knowing how retirement schemes should take into account the hardness of past or current working conditions, that very often constitute prominent determinants of health status, and (b) the question of knowing how these same pension rules should take into account differences in life expectancy, that are generally tied to bad health conditions. France is a country that benefits of a relatively high average life expectancy, but where mortality differentials are quite large across social groups. Global policies that aim at uniform increases in retirement ages ignoring these penibility/health/mortality differentials raise obvious problems of fairness and this has probably contributed to part of the resistance encountered by some reforms. The 1993 and 2003 reforms have partially avoided this problem because they choose to postpone retirement ages by changing conditions on past contribution records, hence essentially affecting skilled and healthier workers having started working and contributing at older ages. Such is also the strategy followed by the new 2013 reform. The 2010 reform, on the other hand, by raising uniformly the minimum retirement age, affected more than proportionately less skilled workers (Blanchet and Le Minez, 2012) that were, up to now, the main beneficiaries of the French low minimum age at retirement, and who could consider this as a fair compensation for their generally much shorter life horizons.

These two apparently opposite points of views concerning the health/retirement issue are not contradictory. An optimal design of retirement schemes requires adequate pathways for individuals that deserve specific treatments, be it for bad health or any other relevant motive, accompanied with some checking that such pathways are not used by individuals for whom they have not been targeted. 
To help thinking about such optimal schemes, some positive knowledge of how health and retirement decisions currently interfere is an obvious intermediate step. It is to this question that the present paper contributes, looking at how various exit routes have been used in the past by French senior workers according to their observed health status. It will be organized in five sections. Section 2 will come back on the general description of the disability route to retirement in France and how its share in global transitions to retirement has changed over time. Section 3 presents the empirical method used to estimate the exit rate from the labor market of older workers according to their health status. Results are given in section 4 and section 5 is devoted to some simulations of how older workers retirement behavior would change, for a given health status, when the relative generosity of the different retirement routes changes.

\section{Background}

The development of the French pension system took place in several steps all over the twentieth century. The first large scale system was developed in 1920 ("retraites ouvrières et paysannes") then replaced in 1941, during World War II by the AVTS ("Allocation aux Vieux Travailleurs Salariés"), under the Vichy government. It provided early retirement for workers above 60 excluded from the labor force either for health or economic reasons. But the real birth of the pension system we are still living in today occurred just after World War II, when a large welfare state started being developed with a specific part devoted to old age. The initial value for the normal retirement age had been set at 65 , considered as the typical average threshold at which individuals started being unable to maintain their standards of living through labor force participation, be it for health or other reasons and thus had to become eligible to old-age benefits.

However, specific health conditions were also taken into account by the designers of the welfare system and still provide the basic structure of what will be called here the "invalidity" pathway to retirement. Before 60, people suffering from health troubles implying work limitations are eligible to disability insurance benefits (pension d'invalidité). Then, reaching 60, these people already benefiting from invalidity insurance directly shift to old-age disability benefits (retraite pour ex-invalides). And individuals declared unable to work at 60 , but who did not previously benefit from invalidity benefits are also eligible to old-age disability benefits (retraite pour inaptitude). For quite a long time this second category remained however highly selective: it required a disability rate of $100 \%{ }^{5}$, was limited to people having worked for at least 30 years, and provided a benefit being, at the maximum, equal to $40 \%$ of the average of past wages. This was higher than the rate of replacement for people claiming early retirement at 60 without this invalidity motive but remained little attractive.

\footnotetext{
${ }^{5}$ The disability rate measures the intensity of limitations encountered by the disabled person.
} 
For several years also, the global generosity of the whole pension system remained limited. Until the end of the 60s, poverty remained widespread among older age groups. A reaction took place during the 1970s, and several changes progressively increased the coverage and level of pension benefits. This period was also a relatively dynamic period for the development of the pension d'inaptitude, in a context marked by strong union pressure in favor of lowering the normal retirement age to 60 for the entire population. During the 1970s, that demand remained unsatisfied, but the Boulin reform in 1971 opened several possibilities for earlier exits for various categories of population, including a move toward less selective and more generous rules for the pension d'inaptitude: the threshold for the rate of invalidity was lowered to $50 \%$, the condition of having worked 30 years or more was suppressed and benefits were increased to $50 \%$ of the average wage, i.e. in line with a normal full rate pension.

This mechanically led to an increased importance of this route, but, as shown on Figure 2, the incidence of this change was more pronounced for women, because men, at the same period, had also started benefiting from the development of another early retirement route, financially more attractive, i.e. "preretirement", initially developed to cope with severe reductions of activity that had taken place in some traditional industries, such as the steel industry, but that progressively expanded as a major instrument offered to employers and employees for facilitating all forms of early exits from the labor force. This preretirement route initially concerned workers in the 60-64 age group.

\section{(Insert figure 2)}

From 1983 access to a full pension at age 60 became possible for the large majority of the population, the only condition being to have contributed to the pension system for at least 37,5 years. In this context, claiming for a pension d'inaptitude became useless for a large share of people. Those who still had a reason to rely on this route were people reaching the age of 60 in bad health and with incomplete careers.

This situation has started to evolve again over the last decade. Four reforms have been conducted that have strongly reduced the possibilities to leave as early as 60 , and specifically the 2010 reform that has shifted the minimum age to 62 , with only limited derogations for earlier exits. It is in this new context that the health/invalidity/retirement link has started reemerging as an important topic, both from an academic and an operational viewpoint. On the operational side, the pension reform that took place in 2003, while making more difficult general access to full rate pensions at 60 , introduced new possibilities for exits before 60 for workers having started working very early, expected to suffer, on the average, from harder working conditions and lower health status than more skilled workers having started their careers at much later ages. This 2003 reform was also expected to be followed by negotiations between social partners specifically devoted to the situation of workers suffering from difficult working conditions affecting their health status. Although these negotiations remained unable 
to deliver tangible results, this shows how important the problem is now considered to be. The issue implicitly or explicitly reemerged with the 2010 reform. Opponents to the reform pointed at consequences of a uniform increase in the minimum retirement age for all workers including those with bad health, low life expectancies or who have experimented bad working conditions. A partial answer to this concern has been to finally maintain the threshold of 60 for people with a level of impairment of at least $50 \%$.

\section{Empirical strategy}

Stylized facts concerning the relative importance of the French disability route are already wellknown. Behaghel, Blanchet, Debrand and Roger (2012) have shown that, until now, alternative routes have exempted French workers from massively relying on disability motives for early exits over the past decades but put forward that a decrease in the generosity of other routes may induce people in bad health to claim disability benefits. Results of these authors are mostly on substitution effects between the several retirement pathways available to old age workers. In the sequel, the objective is to go some steps further, by looking in more details at how retirement behavior is affected by the availability of the various routes out of the labor force and how this availability interacts with actual health status. We shall consider incentives provided by disability insurance programs but also by old-age specific unemployment benefits programs and early or normal retirement benefit rules, in addition to those provided by normal pension rules.

Some difficulties arise when one wants to estimate the causal links between retirement and health at old age. Labor force attachment, health and relative gains associated to the different pathways may be driven by common unobservable factors like abilities, preferences or family events. Among other, for instance, the disability route is advantageous for those with short careers. Following the choices made in previous waves of the ISS program, we rely on an Option Value indicator (Stock and Wise 1990) of the incentives to leave the labor market to disentangle the effect of health versus incitation in the retirement behavior. The Option Value indicator measures the value to continue working compared to the value provided by other options in a dynamic framework. The OV indicator islabeled "inclusive" in the sense that it tries to provide a synthetic weighted summary of the Option Values associated with each possible path to retirement.

The inclusive OV summarizes the main characteristics of the French retirement system and alternative routes into a single indicator. Among the many difficulties of such an exercise, one stems from the intrinsic complexity of the French system and of the various routes offered to workers considering leaving the labor force. To keep things tractable, we restrict ourselves to "normal retirement" for wage earners or civil servants. Concerning access to old age unemployment support and pre-retirement, a one-by-one inclusion of all the possibilities that have existed over the period is beyond the scope of this paper and would probably be of little interest, given the very aggregate nature 
of the index we are trying to build. Our approach is instead to proxy all these routes by the dominant one for each period, giving to this route a global weight equal to the total flow of early retirees or unemployed for each period.

The incentive indicator for the disability pathway has been simulated following assumptions that will be described later. Once this made, we shall be able to compute an Inclusive Option Value as:

$$
O V_{t}^{\text {inc }}(t)=\alpha_{D I} O V_{t}^{D I}(t)+\alpha_{U E R} O V_{t}^{U E R}(t)+\left(1-\alpha_{D I}-\alpha_{U E R}\right) O V_{t}^{\text {normal }}(t)
$$

where $O V_{t}^{i n c}$ is the inclusive Option Value, $O V_{t}^{D I}$ is the Option Value for the disability pathway, $O V_{t}^{U E R}$ is the Option Value for the unemployment-early retirement pathway, $O V_{t}^{\text {normal }}$ is the Option Value for normal retirement and where $\alpha_{D I}$ and $\alpha_{U E R}$ are the relative weights of the DI and unemployment/preretirement pathways.

The main objective of the article being to disentangle the impact of incentives and health status on labor force participation, we introduce simultaneously the OV and individual health indicators in regressions explaining employment status. The generic equation that is estimated is therefore:

$$
\operatorname{Pr}(\text { retire }=1)=\Phi\left(\beta O V^{\text {inc }}+\gamma \mathrm{I}^{\text {health }}+\delta X\right)
$$

with retire equal to 1 for individual not in employment, $O V{ }^{\text {inc }}$ the inclusive Option Value, $I^{\text {health }}$ the individual health indicator and $X$ some individual characteristics. Regressions are also performed separately by health quintiles. The estimations are conducted with probit models specification and standard error clustered at the individual level.

The labor force participation and health indicators are taken from the French data of the Survey of Health, Ageing and Retirement in Europe. SHARE is a multidisciplinary and cross-national panel database of micro data on health, socio-economic status and social and family networks of more than 85,000 individuals aged 50 or over from 19 European countries. The sample size for France is around 3000 households interviewed every two years since 2004. Data collected include information on individual labor market status and numerous health variables: self-reported health, health conditions, physical and cognitive functioning, health behavior, use of health care facilities. Data on labor force participation are issued from SHARELIFE, the third wave of data collection for SHARE. This wave provides some complementary information on people's life histories. The health indicator is based on waves 1 and 2 of the survey. 
Before moving to the results, we detail the components of the regression model in the following subsections. The first subsection is devoted to the presentation of the pathways, the second to the weighting of these different pathways, the third to the computation of the Option Values, the fourth to the presentation of the health indicator and the last to the presentation of the main characteristics of the employment data.

\section{3.a. Pathways to retirement and participation to the labor force}

We summarize the pathways to retirement in three categories: the normal retirement pathways (main route), the sick leave and disability pathways (routes of interest) and the preretirement/unemployment pathway (others). The preretirement/unemployment pathway not being the focus of the article, we decide to aggregate these two retirement routes which actually display some common characteristics.

The main characteristics of the disability route have been already presented in section 2 . We only recall here the main features of the system. Before 60 , the pension d'invalidité is for individuals with a disability rate over $2 / 3$. Workers can also be on long-term sickness leaves. After 60 , people may be eligible to the pension d'inaptitudefor a disability rate over $1 / 2$ if they didn't get a pension d'invalidité before 60. These people are treated as full rate pensioners even if they do not fulfill conditions for the full rate.

For the normal retirement route, we consider the first pillar basic pension and the second pillar complementary pensions for private sector employees, and the one-pillar pension for civil servants. The basic pension is linked to age at retirement and to $\mathrm{N}$, the number of years of contribution tothe pension scheme. Until 2009, major changes have concerned the condition on $\mathrm{N}$ for getting the full rate before 65 (now 41 years instead of 37,5 in 1992), the replacement rate at this full rate and the penalties and bonuses for retiring before or after this full rate. In 2009, the mandatory age has been shift to 70 and, in 2010, it is the minimum retirement age that has been shifted to 62. Accordingly, the age for getting the full rate without the requested value of $\mathrm{N}$ has been also increased by two years, shifted from 65 to 67 . A new reform is under way for 2013 that will again affect the condition on $\mathrm{N}$ rather than the age bracket for access to retirement. Figure 3 provides a very synthetic view of the recent changes in the main parameters of the pension scheme illustrating how past reforms have changed the relationship between retirement age and the replacement rate, for an individual that under pre-1993 conditions, was already unable to get the full rate at 60 .

The Preretirement/unemployment pathway provides a given percentage of the reference wage at an age that has varied between 56 and 57 over the past. Here, we have retained a stylized profile for this eligibility age and a fixed replacement rate of $60 \%$. We consider a fixed replacement rate, which is the characteristic of most of these programs. The major differences concern eligibility ages, not fully 
homogenous across subroutes and not constant over the past decades. People in early-retirement or in unemployment go on validating years of contribution when aged over 55 until they are entitled to the full rate pension.

Figure 4, from Behaghel, Blanchet, Debrand and Roger (2012), shows the pathways to retirement of men and women from 1983 to 2003.We see a decrease in the share of people still in employment just before their sixtieth birthday and an increase in the shares of people in early retirement or benefiting from unemployment insurance benefits. All over the period, the number of people going through disability insurance or sickness leave is not negligible, but remains small, amounting to between 5 percent and 8 percent of the population.

\section{(Insert figures 3 and 4)}

\section{3.b. Weighting the Pathways to Retirement}

The retrospective presentation of the pathways underlines the changes over the last decades. People from different cohorts experience different opportunities at the end of their working lives. Pathways in figure 4 are proxied by the situation at age 59 in the French Labor Force Survey corrected with administrative data on unemployment, early retirement and complemented with administrative data on sickness leave and inflows from pension d'invalidité to pension d'inaptitude. We have the information at the population level. To disaggregate the pathways by gender or education, we use another French survey mixing information on disability and labor market histories to compute the relative weights of the retirement pathways, by cohorts, over the last decades.

The data are issued from the French Survey Santé etItinéraireProfessionnel (Health and Labor Market history). The survey provides current and retrospective information on health and labor market status for 14000 individuals aged 20 to 74 in 2006. All successive spells ${ }^{6}$ in labor market histories and all major health events in individual's lives are reported. Moreover, the survey provides general socioeconomic information on the characteristics of households and information pertaining to periods before entry in the labor market. We select a subsample of spells corresponding to the states experienced by the individuals of the sample when aged from 55 to 60 years old. The states are classified in four categories: employment, disability or sickness leave, early-retirement or unemployment (with unemployment benefits) and retired or out of the labor force.

We make several assumptions to compute the relative weights. We consider that the DI path is relevant for everybody and not only for those who seem to have ex-ante some obvious (observed) reasons to consider the choice of applying for DI. The amount of information required to be able to

\footnotetext{
${ }^{6}$ Due to the complexity of some labor market trajectories, unemployment and inactivity under 1 year are not sampled.
} 
know if the DI path is a realistic prospect for an individual may be very high and the assumptions we should have to make very strong. We thus impute to each individual, considering a few individuals characteristics, the mean value of the cell, i.e. the probability to experiment each pathway for all individuals having the same characteristics. The probabilities are calculated using the share of the population for the combined age groups 55-60 on each state at a given point in time.

Figure 5 provides the stock estimator of the pathways probabilities by year between 1990 and 2007. The share of the Disability and sickness leave route increases from less than 4 to nearly $8 \%$ over the period. However, the level remains quite low. The share of the Unemployment and earlyretirement route also nearly doubles during the period, but on a higher level. It goes from 8 to nearly $16 \%$, being the highest around 1998 when disability and sickness leave route exhibit a slight decrease after 8 years of monotonous increase.

\section{(Insert figure 5)}

The decline in the disability and sickness leave route around 1998 is mostly due to men (Figure 6). It occurs at the same time as an increase in the probability to leave the labor force through the unemployment and early retirement route. Trends for women (Figure 7) are less clear. This is the case for most indicators on the labor market over the period, with two phenomena occurring at the same time: changes in the relative situation of older workers on the labor market on the one hand and the increase in women's labor force participation over the past decades on the other hand.

\section{(Insert figures 6 and 7)}

Retirement routes are also distinct by education level. Figures 8 and 9 draw the pathways probabilities by education and age at leaving school. The probability to experiment DI is higher for the less educated. At the beginning of the period, the more educated (or those having left school later) didn't use the disability or sickness leave route. Their propensity to claim for disability pensions increased over the period. Around 2000, the use of DI for the most graduated workers nearly equals the one of individuals with vocational training. The difference by education is more relevant than by gender.

(Insert figures 8 and 9) 


\section{3.c. OV computation}

We will thereafter detail the specific assumptions made, for each pathway, to compute the OV indicators. The OV indicators are based on the Net Present Values (NPV) of retiring at age r, computed at age $t$, and given by:

$$
V_{t}(r)=\sum_{s=t}^{r-1} \pi_{s / t} \beta^{s-t} Y_{s}^{\gamma}+\sum_{s=r}^{\infty} \pi_{s / t} \beta^{s-t}\left(k B_{s}(r)\right)^{\gamma}
$$

With parameters $\beta=0.97$ (discount factor), $\gamma=0.75$ and $\kappa=1.5$ (preference for leisure), and with $\pi_{\mathrm{s} / \mathrm{t}}$ the probability of being still alive at age s conditional upon being alive at $t$, $\mathrm{Y}$ labor income and $\mathrm{B}_{\mathrm{s}}(\mathrm{r})$ the pension benefit that depends upon retirement age $r$.

The option value of not retiring at $\mathrm{t}$ is given by:

$$
G_{t}=V_{t}(r *)-V_{t}(t)
$$

where $\mathrm{r}^{*}$ is the age that maximizes $\mathrm{V}_{\mathrm{t}}(\mathrm{r})$

The normal retirement route consists in the normal basic pension (régime général) plus complementary pensions (ARRCO-AGIRC) for wage earners in the private sector, or of the one-pillar pension applying to civil servants. For these pension schemes, the minimum eligibility age is 60 (the current shift to 62 is without any incidence for the population under review). For the calculation of the incentive, an individual retiring before this age of 60 is supposed to live without resources until this minimum age and then retire immediately even if he does not reach the additional condition required for this pension to be a «full rate » pension. Hence, his NPV will include a zero component until 60, followed by a positive component from 60 to death, at a level that will depend upon whether this individual did or did not reach the full rate at 60 .

For the invalidity route, that covers the two subcases of «pension d'invalidité » and "pension d'inaptitude », an individual exiting through this route at any age before 60 is entitled to $50 \%$ of a reference wage truncated to the social security ceiling, without any condition concerning the length of his past career. The exact formula for this reference wage is the mean wage over the ten best years of this person's career, after truncation. Here, for simplicity, we retain the truncated value of this person's last wage. Then, when reaching the minimum retirement age of 60 , this person is reoriented toward the « inaptitude » subroute, i.e. a computation of a full rate normal pension (including complementary pensions) even if this person does not totalize the number of years of contribution required for the full rate under normal provisions.

For the last route, the unemployment/preretirement route (hereafter «PR»), it offers leaving at an age that, depending upon year of exit, has been alternatively equal to 56 or 57 , with a level of benefit applying to one's last wage truncated to $200 \%$ of the Social Security ceiling, with two different rates 
applied to the share of this last wage below and over the Social Security ceiling. People exiting through this route then go on accumulating years of participation to normal Social Security and start getting their pensions as soon as they reach conditions for this pension to be a full rate one. This route only applies to wage earners in the private sector. Since it is not possible to voluntary quit the labor force at e.g. 55 and wait until the eligibility age for this PR route, exits through the «PR » route are treated as equivalent to exits through the normal route, $i$.e. full inactivity until the minimum retirement age.

Table 1 shows computations associated to the normal route for an individual considering different ages at leaving the labor force when his current age is 55 .

\section{(Insert table 1)}

This person is a private sector worker born in 1930 having started working at 17. If he had chosen to leave the labor force at 55 (in 1985), he would have had to wait until 60 to get a pension of only 10948 equivalent Euros per year. The grey shaded area shows the resulting sequence of discounted utility flows by year: zero utility until age 59 included, then a utility at age 60 of $\left(\kappa^{*} 10498\right)^{\gamma} / \gamma$ that, with $\kappa=1.5$ and $\gamma=0.75$ is equal to 1874 , hence, after correction for survival and discounting, a contribution to intertemporal well-being of 1510. The sum of all these contributions from 55 to the maximum life span was 20955. The same person still at 55 but rather contemplating leaving at 60 could expect at this age a much larger pension of 15170, the gap being due to the 5 additional years of contributions to both the general regime and complementary schemes. In such a case, the discounted sum of utility flows includes non-zero values corresponding to net labor income between 55 and 59 , followed by the flows resulting from the new benefit level, hence a much larger NPV of 37828 .

Considering retirement at still older ages did not lead to large additions to this person's pension benefits, given the rules that applied to this cohort. For this person having started working in 1947 at 17, continued work until 59 warranted a full rate pension at 60 and beyond this age, further increments due to postponing had only small consequences for the level of benefits: they were almost exclusively the result of the accumulation of additional points in complementary schemes. Nevertheless, in this example, retiring later always resulted in a higher NPV, despite the choice of a relatively high preference for leisure. The value $\kappa$ equal to 1.5 means that, in the short run, the individual is better off once retired instead of working as soon as his replacement rate is higher than $66 \%$, and such is the case here after age 60 . But the resulting short run loss in well-being in case of postponement remains more than compensated by the fact of getting a slightly higher pension all over the retirement period. As a result, viewed from 55, the age maximizing the NPV was 65 , and the option value of going on working at 55 was $\operatorname{NPV}(55,65)-\mathrm{NPV}(55,55)=39106-20955=18151$, reported in the bottom cell of the table. 
How are these incentive measures distributed among the whole population under review and for the three different routes considered in this study? The left panels of Figure 10 show mean OVs associated to these three routes for respectively men and women from our sample. By construction, OVs at 55 are the same with the normal and the PR route, and then a break is observed for these OVs at 56 and 57 for the PR route while OVs for the normal route decline much more gradually.

The disability route, after 56 or 57 , has characteristics that are very similar to the PR route, replacement rates being roughly similar. The main difference is therefore the fact that this route does not entail any age condition, hence a much lower option value of going on working for people having access to this route as soon as age 55 .

Graphs on the right panels give the percentages of people for which OVs turn negative at each ages, i.e. those reaching an age where leaving the labor force provides a discounted utility flow higher than the one potentially derived from retiring at any later age. Despite the relative generosities of benefits offered through the Invalidity and PR routes, these proportions remain low or even zero until the minimum retirement age. The reason is again that, for the specification of $\gamma$ and $\kappa$, staying in the labor force is always preferable to exiting as long as the replacement ratio falls short of the inverse of the $\kappa$ parameter that measures preference for leisure. Here, $\kappa$ is equal to 1.5 , meaning that net replacement rates higher than $66 \%$ are a necessary condition to make immediate exits welfare improving. Such replacement rates are almost never obtained before the age of 60 . It is only after the minimum retirement age that such replacement rates start occurring, yet only through the normal and invalidity routes. This explains the full superposition between profiles for the normal and preretirement route at all ages: those people that find profitable to exit through the « $\mathrm{PR} »$ route are in fact those who could directly move from the PR to the normal route and leave the labor force with a sufficiently high level of their normal pension, with, as expected, one first spike at the minimum age of 60. This spike is much more pronounced for the invalidity route, as this route amounts to systematically offering a full rate normal pension at this age whatever the past record of Social Security contributions.

(Insert figure 10)

\section{3.d. Measuring Health}

The health index is computed using the SHARE data following the methodology developed by Poterba, Venti and Wise (2010) on the American Health and Retirement Survey data. The authors assume that latent health is revealed by responses to the long list of questions asked in the survey relative to health status and changes in health status. The health index is then defined as the first principal component of these selected health measures. It is a weighted average of the health indicators 
with weights chosen to maximize the proportion of the variance of the individual health index that can be explained by this first principal component. This methodology has been replicated on 25 questions of the SHARE questionnaire. Details on the selected question and on the weights are provided in appendix 1 and in Coile, Milligan and Wise (2013)

The percentiles of health, by age and sex are given in figure $11^{7}$. Percentile 1 corresponds to the worst health, percentile 100 to the best. Unsurprisingly, the health index is decreasing with age and is higher for women than for men.

(Insert figures $11 \mathrm{a}$ and $11 \mathrm{~b}$ )

\section{3.e Employment data}

Data on labor market states are issued from SHARELIFE, the third wave of data collection for SHARE. This wave provides some complementary information on people's work histories. The data collection for SHARELIFE took place between Fall 2008 and Summer 2009. Over a sample of 2,483 individuals for France, we consider 1121 individuals employed at 54 for whom we have information on past careersand on health indicators. Following them from age 54 until retirement provides information on 6274 annual spells. For each observation we have additional information on gender, age at leaving school, skill (executive or not executive), degree, marital status and assets of the household.

Regressions are made on the whole sample but also on a subsample corresponding to health quintiles or education levels. The size of the subsample, the number of observation and the mean retirement rates will be detailed in tables of results with the coefficients of the regressions.

\section{Results}

Table 2a displays the results of probit models of the transition to non-employment, between ages 55 and 64. Transition to non-employment is considered thereafter equivalent to retirement:the transition into employment from any other state of the labor market is rare in this age group so we consider that leaving the labor market after 55 in France is an absorbing state. We include various sets of controls in models (1) to (8). The first four models are estimated using dummy variables for health quintiles. The last four replicate the same specifications but including the health index under a linear

\footnotetext{
${ }^{7}$ The figures are drawn using the lowess smoother of Stata.
} 
assumption instead of health quintiles. The values of the Inclusive OV in the regressions are in units of 10000 .

Results on the inclusive OV are unchanged when we change the specification of the health indicator. The coefficient of the inclusive OV has the expected negative sign and is highly significant, i.e. individuals with higher incentives to delay retirement will effectively do it. The results remain remarkably robust to the various sets of controls. Coefficients for the Inclusive OV are between -0.046 and -0.048 . The effect on the probability of retirement of a one standard deviation change in the $\mathrm{OV}$ is given within brackets in table 2a, under the estimated coefficient. Since this standard deviation is roughly equal to 10000 , our unit for measuring OVs, these simulated effects have the same order of magnitude as estimated coefficients. They range between -0.042 and -0.044 percentage point. Considering the mean level of probabilities to retire, i.e. 0.124 , this implies a decrease of nearly $30 \%$ for these probabilities : this impact is quite large, but it correspond to a change in incentives that is itself quite large, amounting to two thirds of the mean Inclusive Option Value..

Estimates for control variables imply that people in better health tend to retire at older ages. All coefficients on health quintiles are negative and significant in specifications (1) to (4), i.e. individuals in a health quintile higher than the first (worst health quintile) tend to remain longer in the labor market. However, there is no clear trend and a linear assumption on the health effect might be rejected. Coefficients of health quintiles 2 to 5 tend to exhibit an inverted U-shaped pattern.

Probabilities to retire are also higher for men and married people. The higher probabilities for men may result from higher pension entitlement due to longer careers not fully captured by incentive variables. Concerning married people, higher propensities to retire can be due to joint retirement decisions of spouses, especially for women (Sédillot and Walraet, 2003). On the other hand, coefficients for wealth and education are not significant at the 5\% level when these variables are introduced in the regressions. A higher education level decreases the probability to retire, as could be expected, but the results are hardly significant, probably because financial motivations to postpone for more skilled people are, here, appropriately captured by the OV indicator.

\section{(Insert table 2a)}

Figures 12 and 13 display predicted versus actual retirement behavior by age. Predicted hazards and survivals are simulated by age using the estimated coefficients of specification (8) where age effects are captured by dummies rather than with a linear specification. Age effects are introduced to capture progressive changes in preferences for retirement when people get older, but also some possible attraction effects for some specific retirement ages: using dummies is better suited for capturing this second category of age effects. As a general rule, using dummies rather than a linear trend by age does not affect the estimated impact of the OV indicator, but leads, effectively, to a much 
better fit reflected on these figures 12 and 13.However, there remains a slight underestimation of survival rates and an overestimation of hazard ratesaround 62. Results are the same by gender.

\section{(Insert figures 12 and 13)}

Table $2 \mathrm{~b}$ replicates the specifications 1 to 4 (health quintiles) of table $2 \mathrm{a}$ for a different OV indicator. This alternative indicator is computed by averaging, over the three potential routes, the percentage gains from delaying retirement measured by the corresponding OVs at age a divided by Net Present Values of retiring, through this route, at this age a.Averages are computed using the same relative weights as the ones used for the initial Inclusive OV. This new set of estimations confirms that the estimated impact of financial indicators is almost the same whatever the set of control variables introduced in the model.

\section{(Insert table 2b)}

Tables $3 \mathrm{a}$ and $3 \mathrm{~b}$ displays estimates for the same models as in table $2 \mathrm{a}$ and $2 \mathrm{~b}$, but separately for the five health quintiles. The mean retirement rate is decreasing with the level of health from 0.159 for the worst health quintile to 0.096 for the best health quintile. This means that individuals in better health retire at older ages. The effect of financial incentives provided by the pension system is higher in the middle of the health distribution (table 3a). Changes in the probability of retirement associated with a change of one standard deviation for incentives is -0.06 in the $2^{\text {nd }}$ quintile, between -0.04 and 0.05 in the $3^{\text {rd }}$ and $4^{\text {th }}$ quintile and around only -0.02 in the $5^{\text {th }}$ quintile. It is as if choices for individuals in very good health were less dependant on financial incentives, both because good health may be associated to better working conditions that reduce propensity to retire or, quite at the opposite, because a very good health offers opportunities for alternative projects or activities during the retirement period. The low coefficient for the lowest quintile is less counterintuitive as people in bad health may be constrained to retire whatever the financial conditions. The regressions with the gain variable confirm the results of the OV Incentive indicator, but generally less significant. Coefficients are significant only for the $2^{\text {nd }}$ and $3^{\text {rd }}$ health quintiles, i.e. in the middle of the health distribution. Predicted hazards by health quintile are given in figure 14 .

(Insert tables $3 a-b$ and figure 14)

Table $3 \mathrm{c}$ presents the results of models including directly the interaction between health status and the incentive variable, with a linear specification for the health variable. This specification is more constrained than the previous one and less informative :the negative interaction between health 
and Inclusive OV is not statistically significant. But coefficients of the OV inclusive variable remain the same as in specifications (5) to (8) of table 2.

(Insert table 3c)

Last, in table $4 \mathrm{a}$ and $4 \mathrm{~b}$, we present estimations including interactions between education levels and the incentive variables, either the Inclusive OV (table $4 a$ ) or the gain indicator (table $4 b$ ). Unsurprisingly, the higher educated people are, the lower is the mean retirement rate and the higher is the mean of the OV Incentive indicators. The effect of changes in the probability of retirement associated with a one standard deviation of the Inclusive OV is nearly twice as large for high school graduates or above (nearly -0.06 for a mean retirement rate of 0.109 ) compared to high school dropouts (around -0.03 for a mean retirement rate of 0.138 ). Results are not very sensitive to the specification of the model. The general pattern is the same with the gain indicator but with results that are generally less significant.

(Insert tables $4 a$ and $4 b$ )

\section{Simulations}

Results of the previous section have shown that health and incentives provided by the pension system simultaneously impact on individual retirement behavior. We will now simulate changes in the retirement behavior, for a given level of health, for alternative scenarios concerning pension or disability entitlements.

The share of the Disability and sickness leave among the retirement pathways being quite low in France (Figures 4 to 8), the part of this specific path in the inclusive OV is quite slight. We have thus to simulate large changes in the availability of this subroute to observe some impact on the Inclusive OV and thus on retirement behavior.

We first simulate retirement behaviors as if only one exit route were available, normal retirement, unemployment/preretirement or DI. Then, we add two "mixed" scenarios. These two scenarios use unchanged probabilities to exit through the unemployment/preretirement pathway. But probabilities differ concerning exits through the DI pathway for remaining people, respectively $1 / 3$ and $2 / 3$. .

These scenarios are applied first to the whole population and then to the subsample of individuals more directly concerned by DI, i.e. those for which the incentive to retire is higher through 
the DI route than through the normal route, thereafter the "DI" subsample. These people are those whose OVs are lower under DI than under normal retirement, at the time of effective retirement.

\section{(Insert figures 15 and 16 and table 5)}

Simulated results are provided in figures 15 (whole sample) and 16 (DI subsample), using survival functions. They are summarized on table 5 using average years spent at work under the various scenarios, compared both to actual numbers and to the simulated baseline scenario. More precisely, the indicators provide the mean cumulative number of years of work from 55 to retirement, for each scenario. Column 1 provides results for the whole population and column 2 for the DI subsample.

Graphs of survival functions show that all alternative scenarios are bracketed within the two polar cases where only the normal route is accessible or where the DI route is available to $100 \%$ of the population.

When the whole sample is considered, average years of work computed under the baseline scenario are close to the actual figure, respectively 5.509 and 5.652.

The average years of work over the age 55-64 if everyone retires through the normal retirement route is simulated equal to 5.495 , which is almost the same as the baseline value. This result is explained by the predominant weight of the normal retirement route in the Incentive OV indicator. It is lower than the observed average years of work in our sample, 5.652. The simulated average years of work drops to 4.957 if everyone retires through the DI route.Years of work are nearly $14 \%$ greater under the regular retirement incentives than under the DI incentives. DI is the route which implies the lowest number of years of work after 55. Even in the simulation where everyone would have access to unemployment/preretirement at the end of their careers, the mean number of years of work between 55 and 64 would be higher (equal to 5.089).

Moving to the "DI" subsample, average years of work are always lower. The difference in actual averages is quite high: 5.652 for the whole sample, 3.886 for the DI subsample. The estimated model predicts a higher number of years worked after 55, equal to 4.692. Simulations made on this subsample exhibit the same patterns of results as the ones made on the whole sample: the highest number or years of work for incentive of the direct retirement route (4.766), the lowest number of years of work for DI (4.188) and each other situation between these brackets.

\section{Conclusion}

The main objective of this paper was to estimate, for a given health status, which part of the labor force participation at old age is determined by the provisions of disability insurance programs. 
For that purpose, after a presentation of the main features of the DI and other retirement pathways for older workers in France, we estimated the impact of the pension and DI schemes on exits from the labor market, controlling for health status, and using a synthetic Option Value indicator. The OV and health indicators are introduced simultaneously in a probit equation. The dependent variable is the probability to make a transition from employment to non-employment after 55. The model is estimated on the French data of the European SHARE Survey. We conclude unsurprisingly that a decrease in the generosity of the pension and DI schemes (i.e. a higher value of the OV) induces people to stay on the labor market and that people in better health tend to retire at older ages.

In the OV approach, DI incentives enter as a component of a larger inclusive OV indicator. In order to isolate the impact of DI, we relied on simulations. First, we present extreme situations simulating what individual's retirement behavior would have been if each of the three exit route had applied to all individuals, then some mixed scenario with various relative importance of the DI pathway. We show that average years of work between 55 and 64 are nearly $14 \%$ greater when regular retirement incentives are applied to the whole population than when it is DI rules that are systematically applied. We then conduct the same analysis on a subsample of individuals considered as having higher probabilities to be eligible to DI, i.e. a "DI" subsample. The average years of work are always lower for this subsample. The difference in the actual averages is quite high: 5.652 for the whole sample, 3.886 for this selected DI subsample. Simulations made on this subsample exhibit the same patterns as for the whole sample: the highest number or years of work for incentives of the direct retirement route, the lowest number of years of work for DI and each other situation between these brackets.

Of course, such simulations remain theoretical and somewhat disconnected from recent changes in retirement policies in France. As was recalled by Figure 1, French LFP rates for the 55-64 age group have started reincreasing significantly since the mid 2000s, essentially due to successive reforms in the normal retirement route, accompanied by stricter rules for the unemployment/preretirement pathway.Less impact on retirement age could be awaited from reforming a disability pathway that, until now, has remained relatively well-focused on those people whose health status really deserve specific dispositions : a tightening of these rules would have been socially problematic with low financial returns at the global level.

The main contribution of the paper has rather been to illustrate how financial incentives and health status indeed interact to determine retirement behavior, using original SHARE data, complemented with other statistical information. Improving our knowledge of both monetary and non monetary determinants of retirement behavior is of major importance for the ex post and ex ante evaluation of both past and future reforms. 


\section{Bibliography}

Barnay, T. and Jeger, F. (2006) "Quels dispositifs de cessation d'activité pour les personnes en mauvaise santé ?", Drees-Etudes et Résultats, n 492.

Behaghel, L, Blanchet, D., Debrand, T. and Roger, M. (2012) “Disability and Social Security Reforms: the French Case", in Social Security programs and retirement around the world: Historical Trends in Mortality and Health, Employment, and Disability Insurance Participation and Reforms, D. Wise, Eds, NBER/The University of Chicago Press

Blanchet, D. and Le Minez, S. (2012) “Joint macro/micro evaluations of accrued-to-date pension liabilities: an application to French reforms ”, DESE Working Papers, g2012-14, INSEE.

Coile, C., K. Milligan and Wise, D.A. (2013) "Social Security Programs and Retirement Around the World: Disability Insurance Programs and Retirement", mimeo.

Minni, C. (2012) “Emploi et chômage des 55-64 ans en 2011 ”, Dares-Analyses, n 049.

Poterba, J.M., Venti, S.F. and Wise, D.A., (2010), “The Asset Cost of Poor health ”, NBER Working Paper No. 16389

Sédillot, B. and Walraet, E. (2003) "La cessation d'activité au sein des couples: y-a-t-il interdependence des choix ?", Economie et Statistique, 357-358: 79-102.

Stock, J.H. and Wise, D.A. (1990), "The Pension Inducement to retire: An Option Value Analysis", NBER Chapters, in Issues in the Economics of Aging, pages 205-230, National Bureau of Economic Research, Inc. 


\section{Appendix 1: coefficients of the health index}

\begin{tabular}{|l|c|l|l||}
\hline Difficulty walking several blocks & 0.281 & Ever experienced heart problems & 0.162 \\
\hline Difficulty lift/carry & 0.284 & Hospital stay & 0.126 \\
\hline Difficulty push/pull & 0.289 & Home care & 0.211 \\
\hline Difficulty with an ADL & 0.272 & Doctor visit & 0.200 \\
\hline Difficulty climbing stairs & 0.296 & Ever experienced psychological & 0.067 \\
& & problems & 0.124 \\
\hline Difficulty stoop/kneel/crouch & 0.304 & Ever experienced stroke & 0.110 \\
\hline Difficulty getting up from chair & 0.265 & Ever experienced high blood pressure & 0.105 \\
\hline Self-reported health fair or poor & 0.279 & Ever experienced lung disease & 0.091 \\
\hline Difficulty reach/extend arms up & 0.227 & Ever experienceddiabete & 0.024 \\
\hline Ever experienced arthritis & 0.185 & BMI at beginning of period & 0.038 \\
\hline Difficulty sitting two hours & 0.178 & Nursing home stay & \\
\hline Difficulty pick up a dime & 0.152 & Ever experienced cancer & \\
\hline Back problems & 0.161 & & \\
\hline
\end{tabular}

Note: Values are based on data from 2004 to 2006, 5844 observations. 
Table 1: Computation of incentives, an illustration

\begin{tabular}{|c|c|c|c|c|c|c|c|c|c|c|c|c|c|}
\hline & & & \multicolumn{11}{|c|}{ Age of potential retirement } \\
\hline & & & 55 & 56 & 57 & 58 & 59 & 60 & 61 & 62 & 63 & 64 & 65 \\
\hline \multicolumn{3}{|c|}{ Permanent pension once fully retired } & 10498 & 12206 & 13703 & 14199 & 14683 & 15170 & 15685 & 15980 & 16453 & 16730 & 17138 \\
\hline \multicolumn{3}{|c|}{ Net wage if working } & 19079 & 19497 & 19748 & 20147 & 20191 & 20786 & 21068 & 21191 & 21293 & 21230 & 21256 \\
\hline Age & Life probs & Disc. life probs & & & & & & & & & & & \\
\hline 55 & 1 & 1 & 0 & 2164 & 2164 & 2164 & 2164 & 2164 & 2164 & 2164 & 2164 & 2164 & 2164 \\
\hline 56 & 0.988 & 0.959 & 0 & 0 & 2111 & 2111 & 2111 & 2111 & 2111 & 2111 & 2111 & 2111 & 2111 \\
\hline 57 & 0.976 & 0.92 & 0 & 0 & 0 & 2043 & 2043 & 2043 & 2043 & 2043 & 2043 & 2043 & 2043 \\
\hline 58 & 0.963 & 0.881 & 0 & 0 & 0 & 0 & 1987 & 1987 & 1987 & 1987 & 1987 & 1987 & 1987 \\
\hline 59 & 0.949 & 0.843 & 0 & 0 & 0 & 0 & 0 & 1903 & 1903 & 1903 & 1903 & 1903 & 1903 \\
\hline 60 & 0.934 & 0.806 & 1510 & 1691 & 1844 & 1894 & 1942 & 1990 & 1860 & 1860 & 1860 & 1860 & 1860 \\
\hline 61 & 0.919 & 0.769 & 1442 & 1615 & 1761 & 1809 & 1855 & 1901 & 1949 & 1794 & 1794 & 1794 & 1794 \\
\hline 62 & 0.902 & 0.734 & 1375 & 1540 & 1679 & 1725 & 1769 & 1812 & 1858 & 1885 & 1718 & 1718 & 1718 \\
\hline 63 & 0.885 & 0.699 & 1310 & 1467 & 1600 & 1643 & 1685 & 1726 & 1770 & 1795 & 1835 & 1643 & 1643 \\
\hline 64 & 0.867 & 0.665 & 1246 & 1395 & 1522 & 1563 & 1602 & 1642 & 1684 & 1707 & 1745 & 1767 & 1559 \\
\hline \multirow[t]{2}{*}{65} & 0.848 & 0.631 & 1183 & 1325 & 1445 & 1484 & 1522 & 1560 & 1599 & 1622 & 1658 & 1678 & 1709 \\
\hline & $\cdots$ & & & & & & & & & & & & \\
\hline 95 & 0.02 & 0.006 & 11 & 13 & 14 & 14 & 15 & 15 & 15 & 16 & 16 & 16 & 17 \\
\hline 96 & 0.013 & 0.004 & 7 & 8 & 9 & 9 & 9 & 10 & 10 & 10 & 10 & 10 & 11 \\
\hline 97 & 0.008 & 0.002 & 5 & 5 & 6 & 6 & 6 & 6 & 6 & 6 & 6 & 6 & 7 \\
\hline 98 & 0.005 & 0.001 & 3 & 3 & 3 & 3 & 4 & 4 & 4 & 4 & 4 & 4 & 4 \\
\hline 99 & 0.004 & 0.001 & 2 & 2 & 2 & 2 & 2 & 2 & 2 & 3 & 3 & 3 & 3 \\
\hline \multirow[t]{3}{*}{100} & 0.002 & 0.001 & 1 & 1 & 1 & 2 & 2 & 2 & 2 & 2 & 2 & 2 & 2 \\
\hline & & Sum of flows & 20955 & 25629 & 29866 & 32601 & 35257 & 37828 & 38347 & 38534 & 38872 & 38951 & 39106 \\
\hline & & Option value & 18151 & & & & & & & & & & \\
\hline
\end{tabular}


Table 2a: Effect of Inclusive OV on Retirement

\begin{tabular}{|c|c|c|c|c|c|c|c|c|}
\hline & $\begin{array}{l}(1) \\
\text { retire }\end{array}$ & $\begin{array}{l}(2) \\
\text { retire }\end{array}$ & $\begin{array}{l}(3) \\
\text { retire }\end{array}$ & $\begin{array}{l}(4) \\
\text { retire }\end{array}$ & $\begin{array}{c}(5) \\
\text { retire }\end{array}$ & $\begin{array}{l}(6) \\
\text { retire }\end{array}$ & $\begin{array}{c}(7) \\
\text { retire }\end{array}$ & $\begin{array}{l}(8) \\
\text { retire }\end{array}$ \\
\hline OV_Inclusive & $\begin{array}{c}-0.047 * * * \\
(0.006) \\
{[-0.044]}\end{array}$ & $\begin{array}{c}-0.046 * * * \\
(0.006) \\
{[-0.042]}\end{array}$ & $\begin{array}{c}-0.047 * * * \\
(0.006) \\
{[-0.044]}\end{array}$ & $\begin{array}{c}-0.046 * * * \\
(0.006) \\
{[-0.042]}\end{array}$ & $\begin{array}{c}-0.047 * * * \\
(0.006) \\
{[-0.044]}\end{array}$ & $\begin{array}{c}-0.046 * * * \\
(0.006) \\
{[-0.042]}\end{array}$ & $\begin{array}{c}-0.048 * * * \\
(0.006) \\
{[-0.044]}\end{array}$ & $\begin{array}{c}-0.046 * * * \\
(0.006) \\
{[-0.042]}\end{array}$ \\
\hline $\begin{array}{l}\text { Health Quintile } 2 \\
\text { (second lowest) }\end{array}$ & $\begin{array}{c}-0.041 * * * \\
(0.010)\end{array}$ & $\begin{array}{c}-0.041 * * * \\
(0.010)\end{array}$ & $\begin{array}{c}-0.041 * * * \\
(0.010)\end{array}$ & $\begin{array}{c}-0.042 * * * \\
(0.010)\end{array}$ & & & & \\
\hline Health Quintile 3 & $\begin{array}{c}-0.031 * * * \\
(0.011)\end{array}$ & $\begin{array}{c}-0.031 * * * \\
(0.010)\end{array}$ & $\begin{array}{c}-0.034 * * * \\
(0.010)\end{array}$ & $\begin{array}{c}-0.034 * * * \\
(0.010)\end{array}$ & & & & \\
\hline Health Quintile 4 & $\begin{array}{c}-0.029 * * * \\
(0.011)\end{array}$ & $\begin{array}{c}-0.030 * * * \\
(0.011)\end{array}$ & $\begin{array}{c}-0.028 * * * \\
(0.011)\end{array}$ & $\begin{array}{c}-0.029 * * * \\
(0.011)\end{array}$ & & & & \\
\hline Health Quintile 5 & $\begin{array}{c}-0.059 * * * \\
(0.010)\end{array}$ & $\begin{array}{c}-0.057 * * * \\
(0.010)\end{array}$ & $\begin{array}{c}-0.060 * * * \\
(0.010)\end{array}$ & $\begin{array}{c}-0.058 * * * \\
(0.010)\end{array}$ & & & & \\
\hline Health Index & & & & & $\begin{array}{c}-0.010 * * * \\
(0.002)\end{array}$ & $\begin{array}{c}-0.010 * * * \\
(0.002)\end{array}$ & $\begin{array}{c}-0.010 * * * \\
(0.002)\end{array}$ & $\begin{array}{c}-0.010 * * * \\
(0.002)\end{array}$ \\
\hline Men & & & $\begin{array}{l}0.018 * * \\
(0.009)\end{array}$ & $\begin{array}{c}0.017 * * \\
(0.008)\end{array}$ & & & $\begin{array}{c}0.018 * * \\
(0.009)\end{array}$ & $\begin{array}{c}0.017 * * \\
(0.008)\end{array}$ \\
\hline Married & & & $\begin{array}{c}0.035 * * * \\
(0.009)\end{array}$ & $\begin{array}{c}0.034 * * * \\
(0.008)\end{array}$ & & & $\begin{array}{c}0.034 * * * \\
(0.009)\end{array}$ & $\begin{array}{c}0.034 * * * \\
(0.008)\end{array}$ \\
\hline $\begin{array}{l}\text { Educ: Vocational } \\
\text { (ref. no diploma) }\end{array}$ & & & $\begin{array}{c}0.016 \\
(0.011)\end{array}$ & $\begin{array}{c}0.017 \\
(0.011)\end{array}$ & & & $\begin{array}{c}0.015 \\
(0.011)\end{array}$ & $\begin{array}{c}0.016 \\
(0.011)\end{array}$ \\
\hline Educ: HS graduate and above & & & $\begin{array}{l}-0.007 \\
(0.010)\end{array}$ & $\begin{array}{l}-0.006 \\
(0.010)\end{array}$ & & & $\begin{array}{l}-0.006 \\
(0.010)\end{array}$ & $\begin{array}{l}-0.005 \\
(0.010)\end{array}$ \\
\hline $\begin{array}{l}\text { Total assets } \\
\text { (in million euros) }\end{array}$ & & & $\begin{array}{c}0.049 \\
(0.043)\end{array}$ & $\begin{array}{c}0.043 \\
(0.042)\end{array}$ & & & $\begin{array}{c}0.044 \\
(0.044)\end{array}$ & $\begin{array}{c}0.039 \\
(0.043)\end{array}$ \\
\hline Age & Linear & Dummies & Linear & Dummies & Linear & Dummies & Linear & Dummies \\
\hline \# of observations & 6,274 & 6,274 & 6,274 & 6,274 & 6,274 & 6,274 & 6,274 & 6,274 \\
\hline \# subjects & 1121 & 1121 & 1121 & 1121 & 1121 & 1121 & 1121 & 1121 \\
\hline Mean Retirement Rate & 0.124 & 0.124 & 0.124 & 0.124 & 0.124 & 0.124 & 0.124 & 0.124 \\
\hline Mean of OV & 15055 & 15055 & 15055 & 15055 & 15055 & 15055 & 15055 & 15055 \\
\hline Std. Dev. Of OV & 10255 & 10255 & 10255 & 10255 & 10255 & 10255 & 10255 & 10255 \\
\hline
\end{tabular}

Robust standard errors in parentheses, $* * * \mathrm{p}<0.01, * * \mathrm{p}<0.05, * \mathrm{p}<0.1$

Note: Coefficients are marginal effects of a 10000 unit change in OV from probit models. The effect of a one standard deviation change in OV is shown in brackets 
Table 2b: Effect of \% Gains in Inclusive OV on retirement

\begin{tabular}{|c|c|c|c|c|}
\hline & $\begin{array}{c}(1) \\
\text { retire }\end{array}$ & $\begin{array}{c}(2) \\
\text { retire }\end{array}$ & $\begin{array}{c}(3) \\
\text { retire }\end{array}$ & $\begin{array}{c}(4) \\
\text { retire }\end{array}$ \\
\hline$\%$ Gain in $\mathrm{OV}$ & $\begin{array}{c}-0.039 * * * \\
(0.013)\end{array}$ & $\begin{array}{c}-0.037 * * * \\
(0.012)\end{array}$ & $\begin{array}{c}-0.040 * * * \\
(0.012)\end{array}$ & $\begin{array}{c}-0.038 * * * \\
(0.012)\end{array}$ \\
\hline Age & Linear & Dummies & Linear & Dummies \\
\hline Health Quintiles & $\mathrm{x}$ & $\mathrm{x}$ & $\mathrm{x}$ & $\mathrm{x}$ \\
\hline OtherXs & & & $\mathrm{x}$ & $\mathrm{x}$ \\
\hline \# of observations & 6,274 & 6,274 & 6,274 & 6,274 \\
\hline \# subjects & 1121 & 1121 & 1121 & 1121 \\
\hline Mean Retirement Rate & 0.124 & 0.124 & 0.124 & 0.124 \\
\hline Mean of \% Gain in OV & 0.624 & 0.624 & 0.624 & 0.624 \\
\hline Std. Dev. Of \% Gain in Ov & 0.683 & 0.683 & 0.683 & 0.683 \\
\hline
\end{tabular}

Robust standard errors in parentheses, $* * * \mathrm{p}<0.01, * * \mathrm{p}<0.05, * \mathrm{p}<0.1$ 
Table 3a: Effect of Inclusive OV on Retirement by Health Quintile

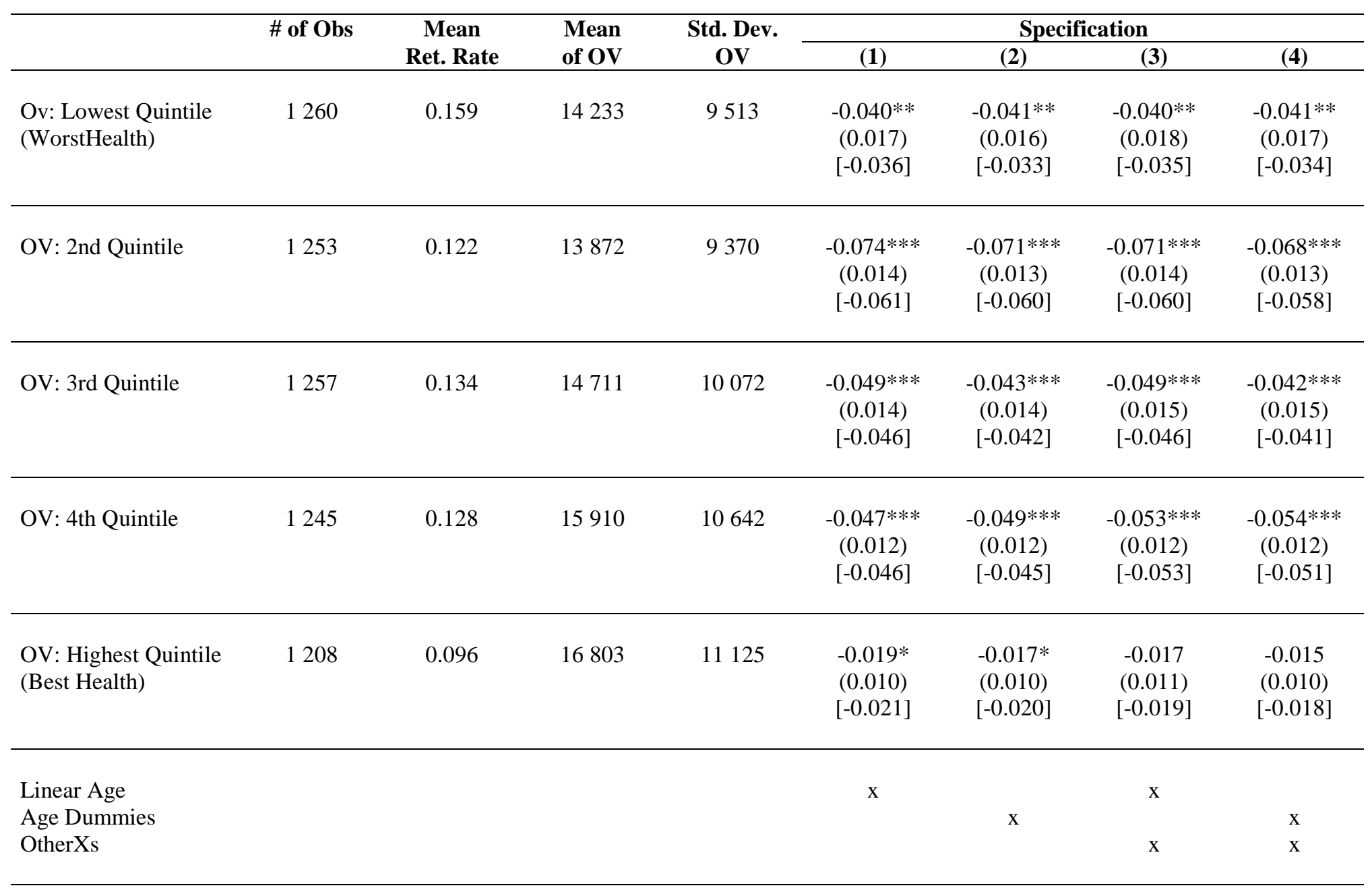


Table 3b: Effect of \% Gain in Inclusive OV on Retirement by Health Quintile

\begin{tabular}{|c|c|c|c|c|c|c|c|c|}
\hline & \multirow[t]{2}{*}{ \# of Obs } & \multirow{2}{*}{$\begin{array}{c}\text { Mean } \\
\text { Ret. Rate }\end{array}$} & \multirow{2}{*}{$\begin{array}{c}\text { Mean } \\
\text { of Gain }\end{array}$} & \multirow{2}{*}{$\begin{array}{c}\text { Std. Dev. } \\
\text { Gain }\end{array}$} & \multicolumn{4}{|c|}{ Specification } \\
\hline & & & & & (1) & (2) & (3) & (4) \\
\hline $\begin{array}{l}\text { Ov: Lowest Quintile } \\
\text { (WorstHealth) }\end{array}$ & 1260 & 0.159 & 0.721 & 0.904 & $\begin{array}{l}-0.012 \\
(0.019)\end{array}$ & $\begin{array}{l}-0.014 \\
(0.018)\end{array}$ & $\begin{array}{l}-0.012 \\
(0.019)\end{array}$ & $\begin{array}{l}-0.014 \\
(0.018)\end{array}$ \\
\hline OV: 2nd Quintile & 1253 & 0.122 & 0.611 & 0.584 & $\begin{array}{c}-0.083 * * * \\
(0.026)\end{array}$ & $\begin{array}{c}-0.084 * * * \\
(0.025)\end{array}$ & $\begin{array}{c}-0.079 * * * \\
(0.026)\end{array}$ & $\begin{array}{c}-0.080 * * * \\
(0.025)\end{array}$ \\
\hline OV: 3rd Quintile & 1257 & 0.134 & 0.569 & 0.537 & $\begin{array}{l}-0.056^{*} \\
(0.029)\end{array}$ & $\begin{array}{l}-0.046 * \\
(0.027)\end{array}$ & $\begin{array}{c}-0.059 * * \\
(0.030)\end{array}$ & $\begin{array}{l}-0.049 * \\
(0.027)\end{array}$ \\
\hline OV: 4th Quintile & 1245 & 0.128 & 0.628 & 0.812 & $\begin{array}{l}-0.034 \\
(0.031)\end{array}$ & $\begin{array}{l}-0.041 \\
(0.030)\end{array}$ & $\begin{array}{l}-0.040 \\
(0.032)\end{array}$ & $\begin{array}{l}-0.046 \\
(0.030)\end{array}$ \\
\hline $\begin{array}{l}\text { OV: Highest Quintile } \\
\text { (Best Health) }\end{array}$ & 1208 & 0.096 & 0.623 & 0.605 & $\begin{array}{l}-0.023 \\
(0.019)\end{array}$ & $\begin{array}{l}-0.017 \\
(0.018)\end{array}$ & $\begin{array}{l}-0.023 \\
(0.019)\end{array}$ & $\begin{array}{l}-0.016 \\
(0.018)\end{array}$ \\
\hline Linear Age & & & & & $\mathrm{x}$ & & $\mathrm{x}$ & \\
\hline Age Dummies & & & & & & $\mathrm{x}$ & & $\mathrm{x}$ \\
\hline OtherXs & & & & & & & $\mathrm{x}$ & $\mathrm{x}$ \\
\hline
\end{tabular}


Table 3c: Effect of Inclusive OV on Retirement with Health Index Interaction

\begin{tabular}{|c|c|c|c|c|}
\hline & $\begin{array}{l}(1) \\
\text { retire }\end{array}$ & $\begin{array}{l}(2) \\
\text { retire }\end{array}$ & $\begin{array}{l}(3) \\
\text { retire }\end{array}$ & $\begin{array}{l}(4) \\
\text { retire }\end{array}$ \\
\hline OV_Inclusive & $\begin{array}{c}-0.047 * * * \\
(0.006) \\
{[-0.044]}\end{array}$ & $\begin{array}{c}-0.046 * * * \\
(0.006) \\
{[-0.041]}\end{array}$ & $\begin{array}{c}-0.048 * * * \\
(0.006) \\
{[-0.044]}\end{array}$ & $\begin{array}{c}-0.046 * * * \\
(0.006) \\
{[-0.042]}\end{array}$ \\
\hline Health Index & $\begin{array}{c}-0.018 * * * \\
(0.007)\end{array}$ & $\begin{array}{c}-0.018 * * * \\
(0.006)\end{array}$ & $\begin{array}{c}-0.021 * * * \\
(0.007)\end{array}$ & $\begin{array}{c}-0.020 * * * \\
(0.007)\end{array}$ \\
\hline OV*Health Index & $\begin{array}{l}-0.001 \\
(0.005)\end{array}$ & $\begin{array}{l}-0.001 \\
(0.004)\end{array}$ & $\begin{array}{c}0.000 \\
(0.005)\end{array}$ & $\begin{array}{c}0.000 \\
(0.005)\end{array}$ \\
\hline $\begin{array}{l}\text { Age } \\
\text { OtherXs }\end{array}$ & Linear & Dummies & $\begin{array}{c}\text { Linear } \\
\mathrm{x}\end{array}$ & $\begin{array}{c}\text { Dummies } \\
\mathrm{x}\end{array}$ \\
\hline $\begin{array}{l}\text { \# of observations } \\
\text { \# subjects }\end{array}$ & $\begin{array}{l}6,274 \\
1121\end{array}$ & $\begin{array}{l}6,274 \\
1121\end{array}$ & $\begin{array}{l}6,274 \\
1121\end{array}$ & $\begin{array}{l}6,274 \\
1121\end{array}$ \\
\hline $\begin{array}{l}\text { Mean Retirement Rate } \\
\text { Mean of OV } \\
\text { Std. Dev. Of OV }\end{array}$ & $\begin{array}{c}0.124 \\
15055 \\
10255\end{array}$ & $\begin{array}{c}0.124 \\
15055 \\
10255\end{array}$ & $\begin{array}{c}0.124 \\
15055 \\
10255\end{array}$ & $\begin{array}{c}0.124 \\
15055 \\
10255\end{array}$ \\
\hline
\end{tabular}

Robust standard errors in parentheses, $* * * \mathrm{p}<0.01, * * \mathrm{p}<0.05, * \mathrm{p}<0.1$

Note: Coefficient are marginal effects of a 10000 unit change in OV from probit models. The effect of a one standard deviation change in $\mathrm{OV}$ is shown in brackets 
Table 4a: Effect of Inclusive OV on Retirement by Education Group

\begin{tabular}{|c|c|c|c|c|c|c|c|c|}
\hline & \multirow[t]{2}{*}{ \# of Obs } & \multirow{2}{*}{$\begin{array}{c}\text { Mean } \\
\text { Ret. Rate } \\
\end{array}$} & \multirow{2}{*}{$\begin{array}{l}\text { Mean } \\
\text { of OV }\end{array}$} & \multirow{2}{*}{$\begin{array}{c}\text { Std. Dev. } \\
\text { OV }\end{array}$} & \multicolumn{4}{|c|}{ Specification } \\
\hline & & & & & (1) & $(2)$ & (3) & $(4)$ \\
\hline OV: < High School & 2150 & 0.138 & 12352 & 8782 & $\begin{array}{c}-0.033 * * * \\
(0.012) \\
{[-0.028]}\end{array}$ & $\begin{array}{c}-0.030 * * \\
(0.012) \\
{[-0.024]}\end{array}$ & $\begin{array}{c}-0.035 * * * \\
(0.012) \\
{[-0.029]}\end{array}$ & $\begin{array}{c}-0.031 * * * \\
(0.012) \\
{[-0.025]}\end{array}$ \\
\hline OV: Vocational & 1265 & 0.132 & 15804 & 9301 & $\begin{array}{c}-0.041 * * \\
(0.017) \\
{[-0.036]}\end{array}$ & $\begin{array}{c}-0.045 * * * \\
(0.017) \\
{[-0.038]}\end{array}$ & $\begin{array}{c}-0.040 * * \\
(0.019) \\
{[-0.035]}\end{array}$ & $\begin{array}{c}-0.044 * * \\
(0.019) \\
{[-0.037]}\end{array}$ \\
\hline OV: High School graduate and above & 1932 & 0.109 & 18010 & 11964 & $\begin{array}{c}-0.059 * * * \\
(0.007) \\
{[-0.060]}\end{array}$ & $\begin{array}{c}-0.055 * * * \\
(0.007) \\
{[-0.058]}\end{array}$ & $\begin{array}{c}-0.058 * * * \\
(0.007) \\
{[-0.061]}\end{array}$ & $\begin{array}{c}-0.054 * * * \\
(0.007) \\
{[-0.059]}\end{array}$ \\
\hline Linear Age & & & & & $\mathrm{x}$ & & $\mathrm{x}$ & \\
\hline Age Dummies & & & & & & $\mathrm{x}$ & & $\mathrm{x}$ \\
\hline OtherXs & & & & & & & $\mathrm{x}$ & $\mathrm{x}$ \\
\hline
\end{tabular}


Table 4b: Effect of \% Gain in Inclusive OV on Retirement by Education Group

\begin{tabular}{|c|c|c|c|c|c|c|c|c|}
\hline & \multirow[t]{2}{*}{ \# of Obs } & \multirow{2}{*}{$\begin{array}{c}\text { Mean } \\
\text { Ret. Rate }\end{array}$} & \multirow{2}{*}{$\begin{array}{l}\text { Mean } \\
\text { of OV }\end{array}$} & \multirow{2}{*}{$\begin{array}{c}\text { Std. Dev. } \\
\text { OV }\end{array}$} & \multicolumn{4}{|c|}{ Specification } \\
\hline & & & & & (1) & $(2)$ & (3) & (4) \\
\hline OV: < High School & 2150 & 0.138 & 0.575 & 0.638 & $\begin{array}{l}-0.010 \\
(0.019)\end{array}$ & $\begin{array}{l}-0.007 \\
(0.019)\end{array}$ & $\begin{array}{c}-0.011 \\
(0.020)\end{array}$ & $\begin{array}{l}-0.008 \\
(0.019)\end{array}$ \\
\hline OV: Vocational & 1265 & 0.132 & 0.610 & 0.513 & $\begin{array}{c}-0.052 * \\
(0.030)\end{array}$ & $\begin{array}{c}-0.057 * \\
(0.030)\end{array}$ & $\begin{array}{c}-0.048 \\
(0.031)\end{array}$ & $\begin{array}{c}-0.053^{*} \\
(0.031)\end{array}$ \\
\hline OV: High School graduate and above & 1932 & 0.109 & 0.621 & 0.584 & $\begin{array}{c}-0.104 * * * \\
(0.018)\end{array}$ & $\begin{array}{c}-0.095 * * * \\
(0.017)\end{array}$ & $\begin{array}{c}-0.100 * * * \\
(0.018)\end{array}$ & $\begin{array}{c}-0.092 * * * \\
(0.017)\end{array}$ \\
\hline Linear Age & & & & & $\mathrm{x}$ & & $\mathrm{x}$ & \\
\hline Age Dummies & & & & & & $\mathrm{x}$ & & $\mathrm{x}$ \\
\hline
\end{tabular}


Table 5 : Simulations

\begin{tabular}{lcc}
\hline & \multicolumn{3}{c}{$\begin{array}{c}\text { Average years of } \\
\text { work }\end{array}$} \\
\hline Actual & Wholesample & DI \\
Baseline & 5.652 & 3.886 \\
Everyone in DI & 5.509 & 4.692 \\
DI=1/3 & 4.957 & 4.188 \\
DI=2/3 & 5.387 & 4.554 \\
Everyone Normal Retirement & 5.231 & 4.384 \\
Everyone in Unemployment & 5.495 & 4.766 \\
\hline
\end{tabular}

Note: $\mathrm{DI}=1 / 3$ means $\mathrm{DI}=1 / 3$ of the observed sum of $(\mathrm{DI}+\mathrm{SS})$ 
Figure 1: Labor force participation for the 55-64 age group

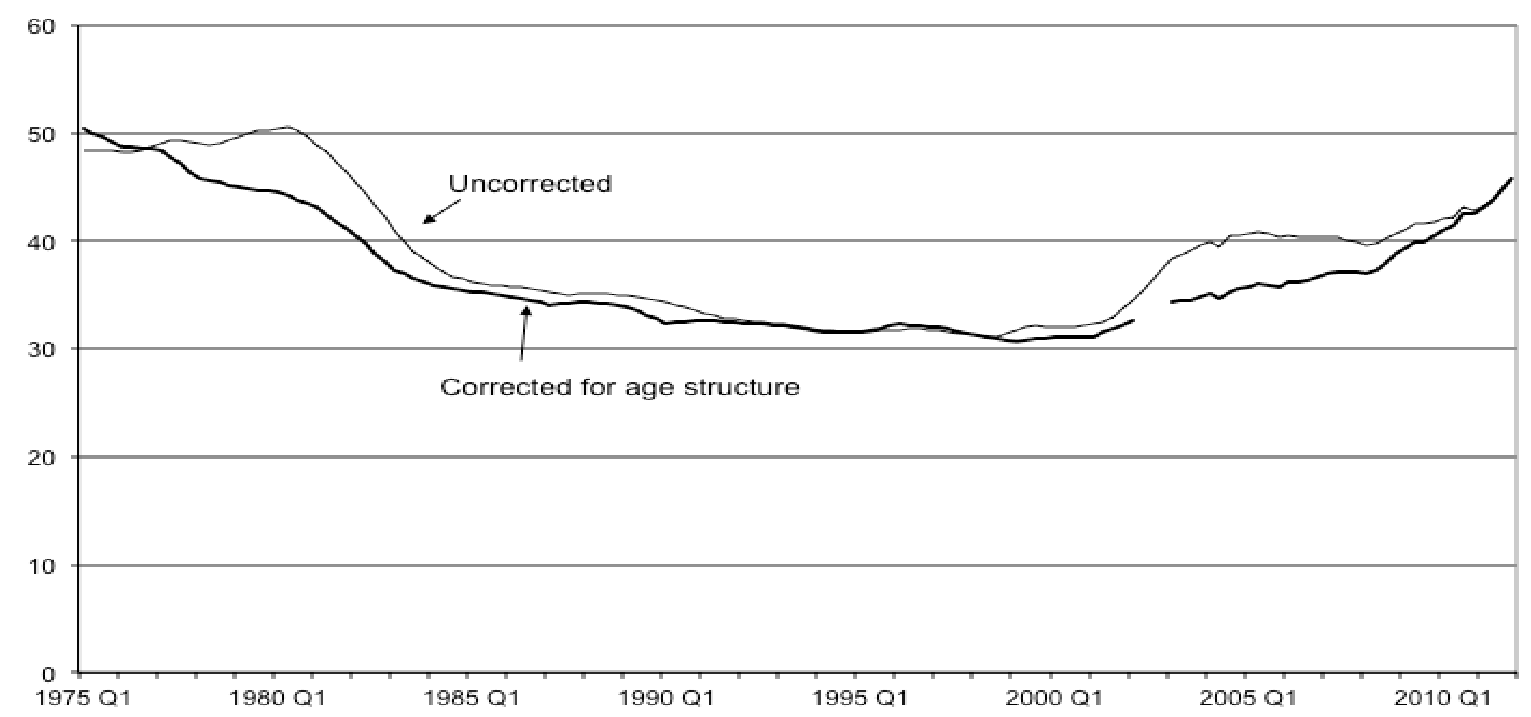

Note : The thin line reports the gross labor force participation rate. The thick line reports a LFP rate corrected for changes in age structure within the 55-64 age bracket. For instance, starting 2001-2002, the gross rate is pushed above its basic trend by the arrival at 55 of the first baby-boom cohorts. The corrected rate neutralizes this temporary phenomenon. The break in 2002-2003 corresponds to the shift from the annual to the continuous time Labor force survey.

Source :Labor Force Survey and Minni (2012)

Figure 2: "pensions d'inaptitude": total flows

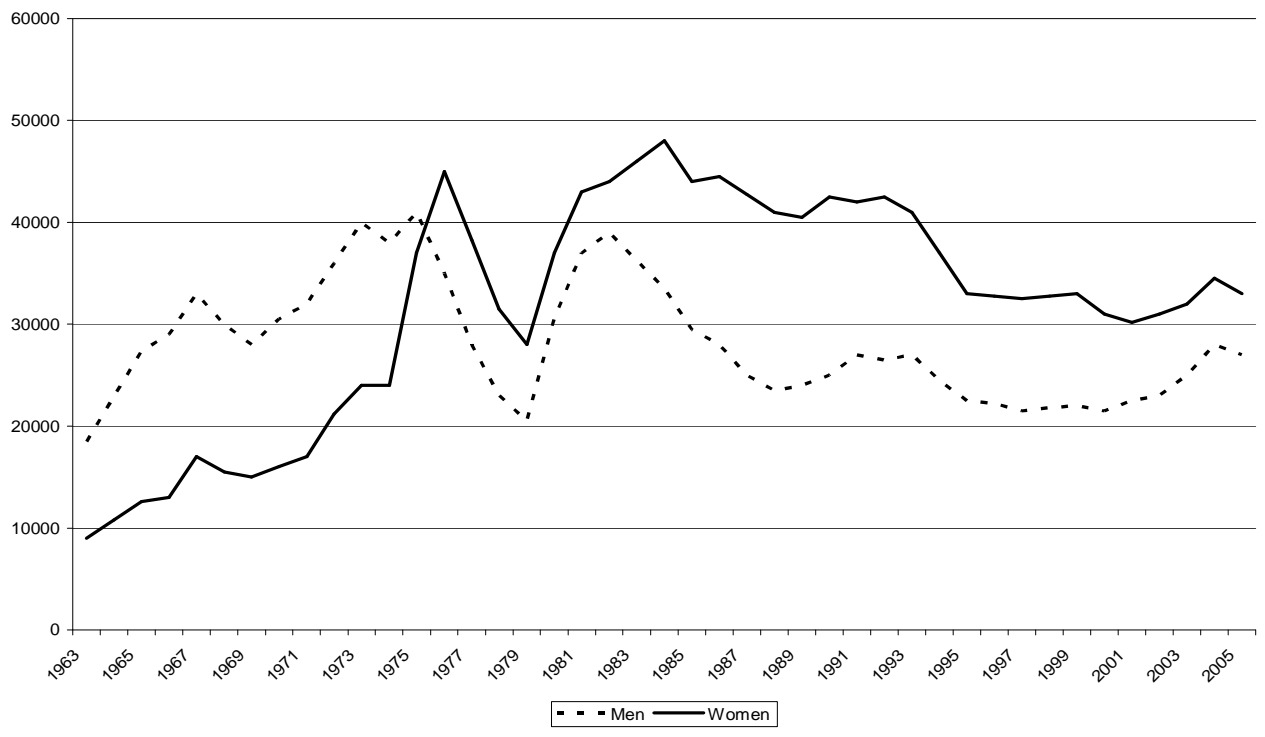

Source: CNAV in Omnès (2006) 
Figure 3: Changes over cohorts for the normal retirement pathway

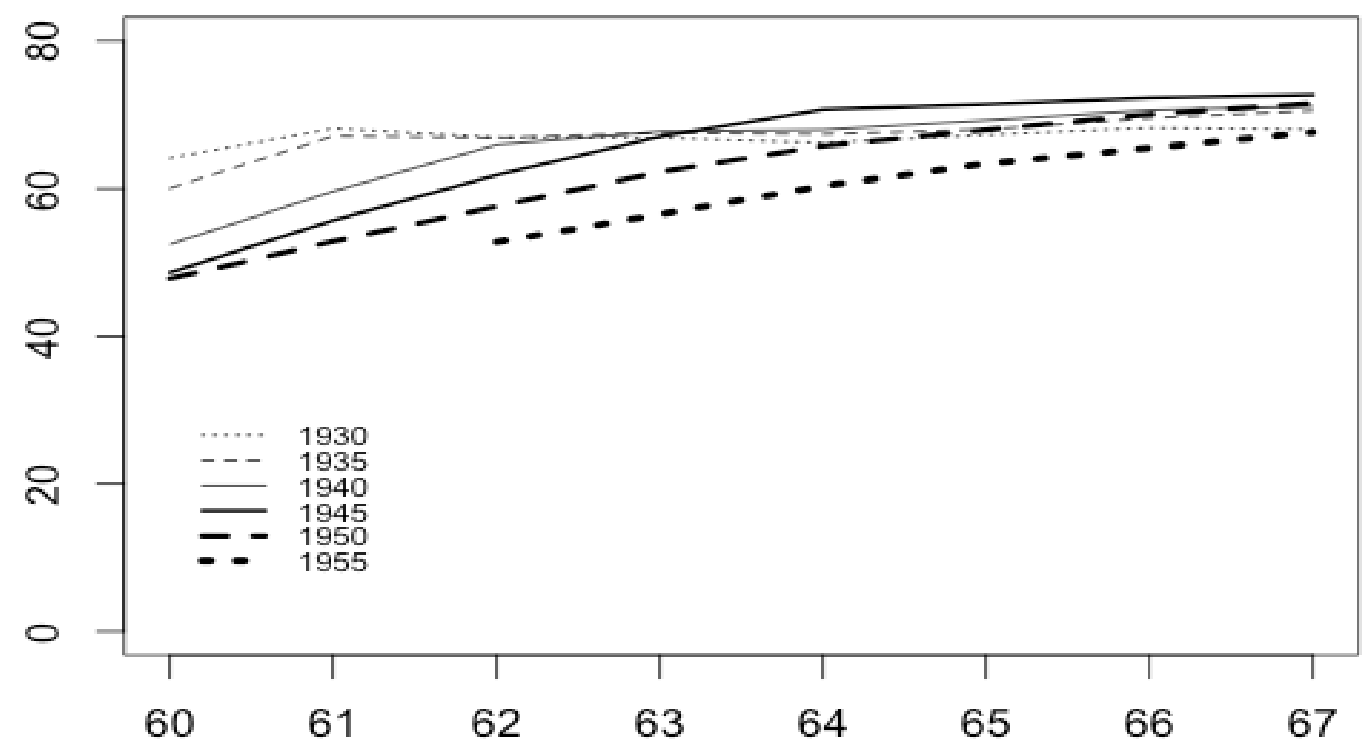

Note : The graph presents the relationship between replacement rates and age at retirement for one illustrative case of worker in six successive cohorts. These illustrative workers are supposed to have worked as wage earners in the private sector, paid at the current Social Security ceiling, since the age of 24 only. This age has been chosen to illustrate how the initial rules penalized workers with careers too short to get a full rate pension at age 60 . The last cohort is affected by the change in the minimum age at retirement, raised from 60 to 62 by the 2010 reform.

Source :Authors computation based on the PENSIPP microsimulation model.

Figure 4: Pathways to retirement, men and women

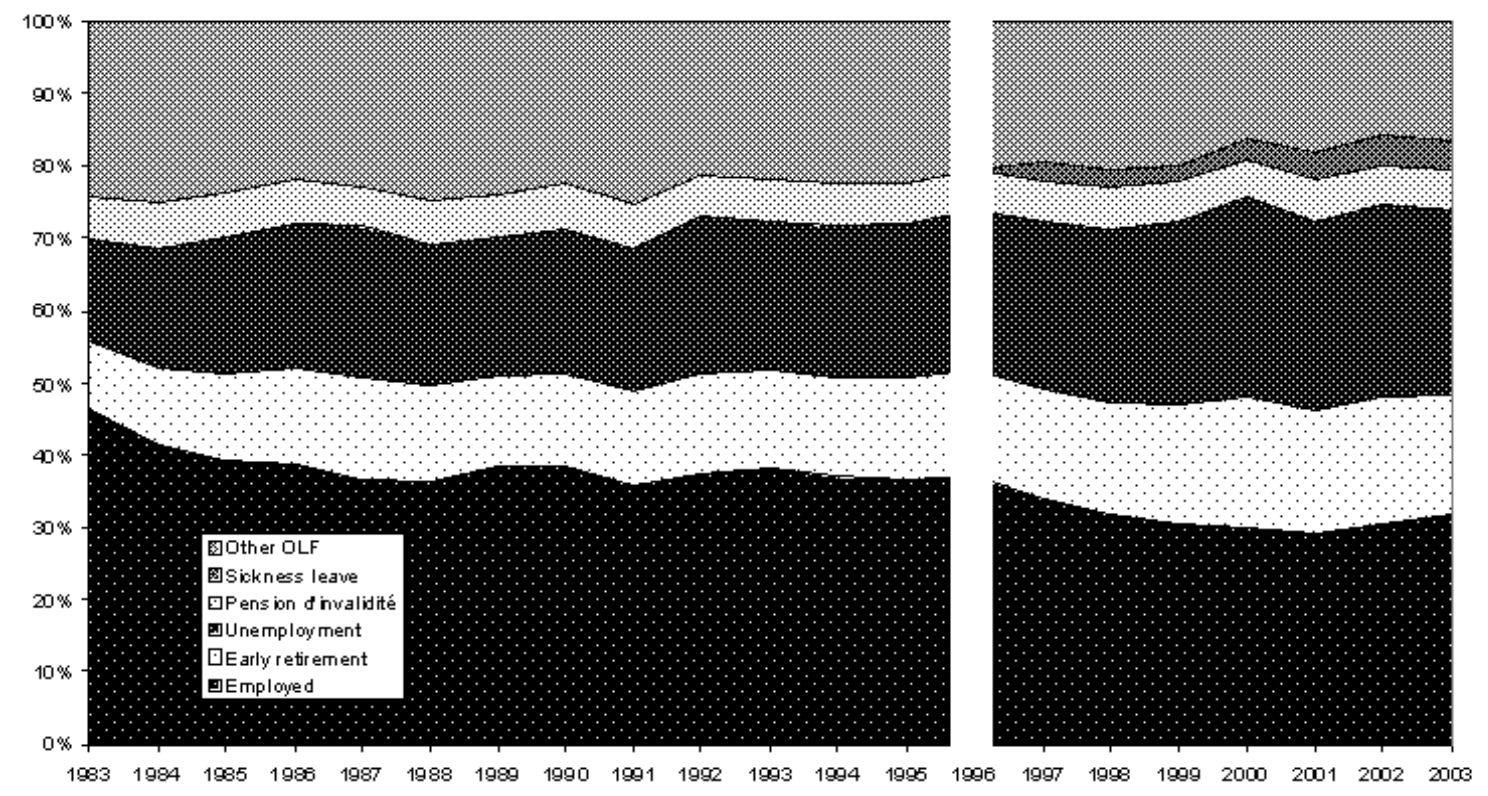

Note: Pathways are proxied by the situation at age 59 (source: EnquêteEmploi) corrected with administrative data on unemployment (source: Unédic), early retirement (source: Dares) and complemented with administrative data on sickness leave (source: CNAM) and inflows from pension d'invalidité to pensions d'inaptitude (source: CNAV).

Break in the series: Data on sickness leave is missing before 1997; before that date, workers in sickness leave are recorded as employed.

Source: Behaghel, Blanchet, Debrand and Roger (2012) 
Figure 5 : Pathway probabilites by year

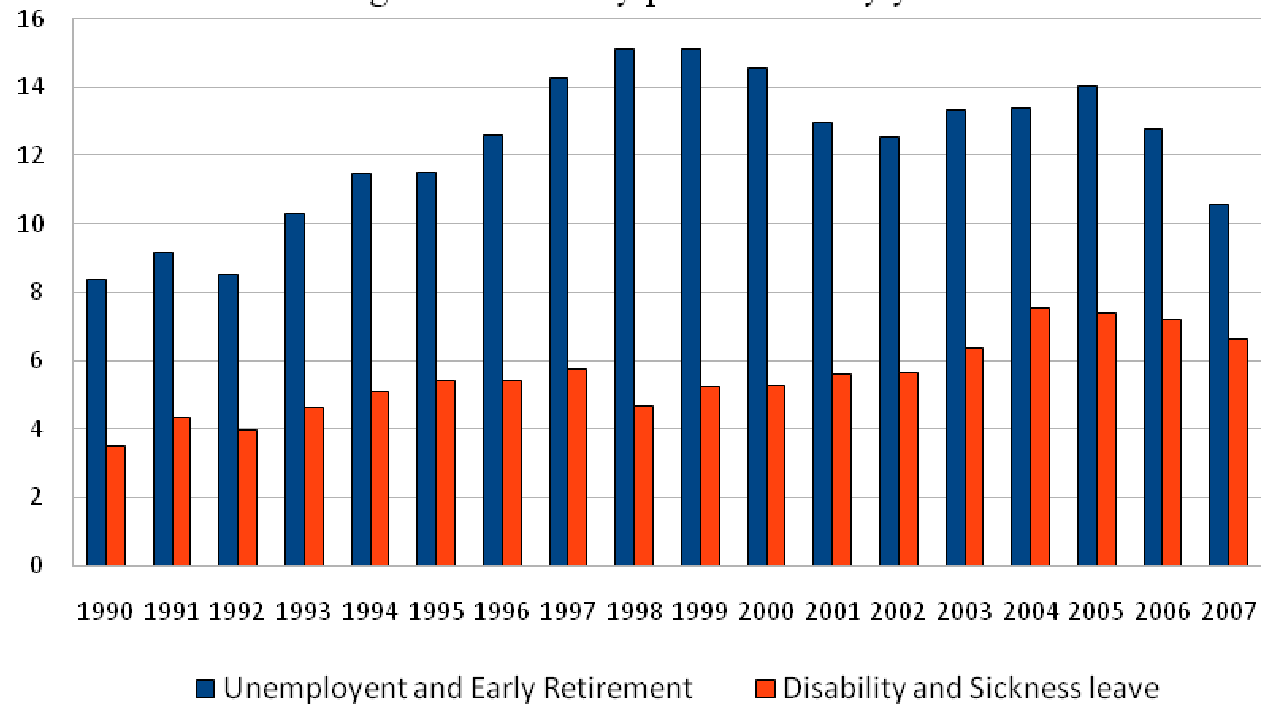

Figure 6: Pathway probabilities by year (men)

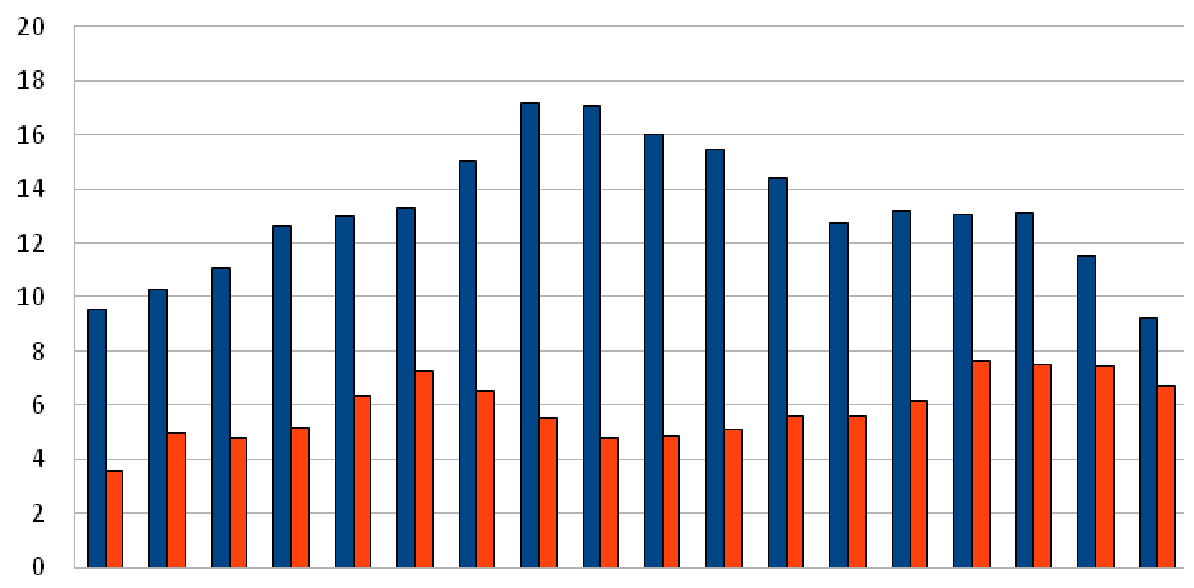

199019911992199319941995199619971998199920002001200220032004200520062007

Unemployent and Early Retirement $\quad \square$ Disability and Sickness leave 
Figure 7: Pathway probabilities by year (women)

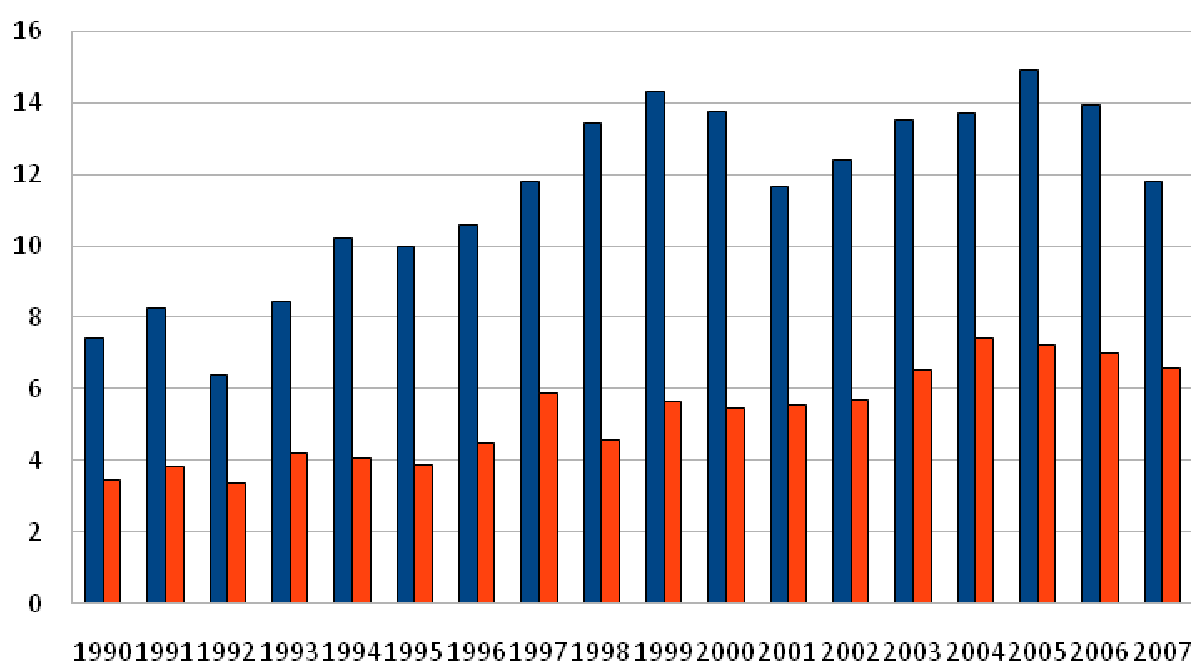

- Unemployent and Early Retirement $\quad$ Disability and Sickness leave

Figure 8: Probability of DI path by education group

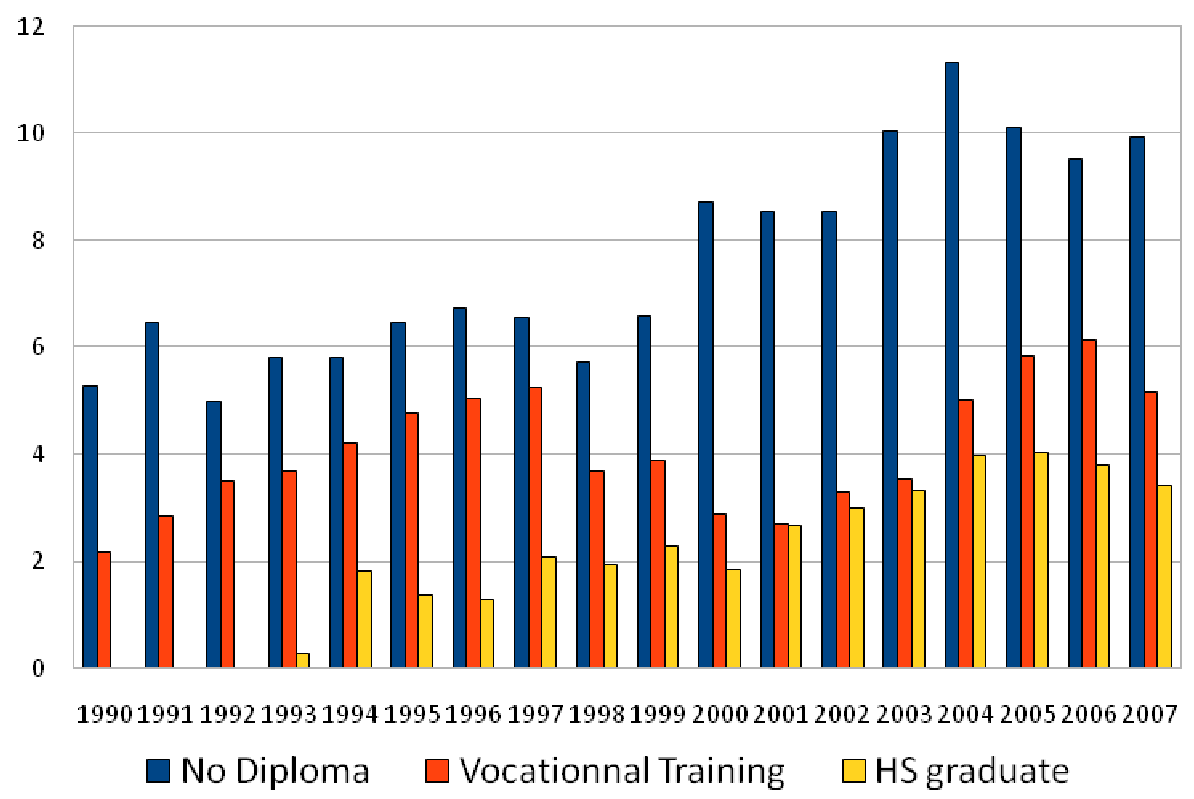


Figure 9: Probability of DI by age at the end of school

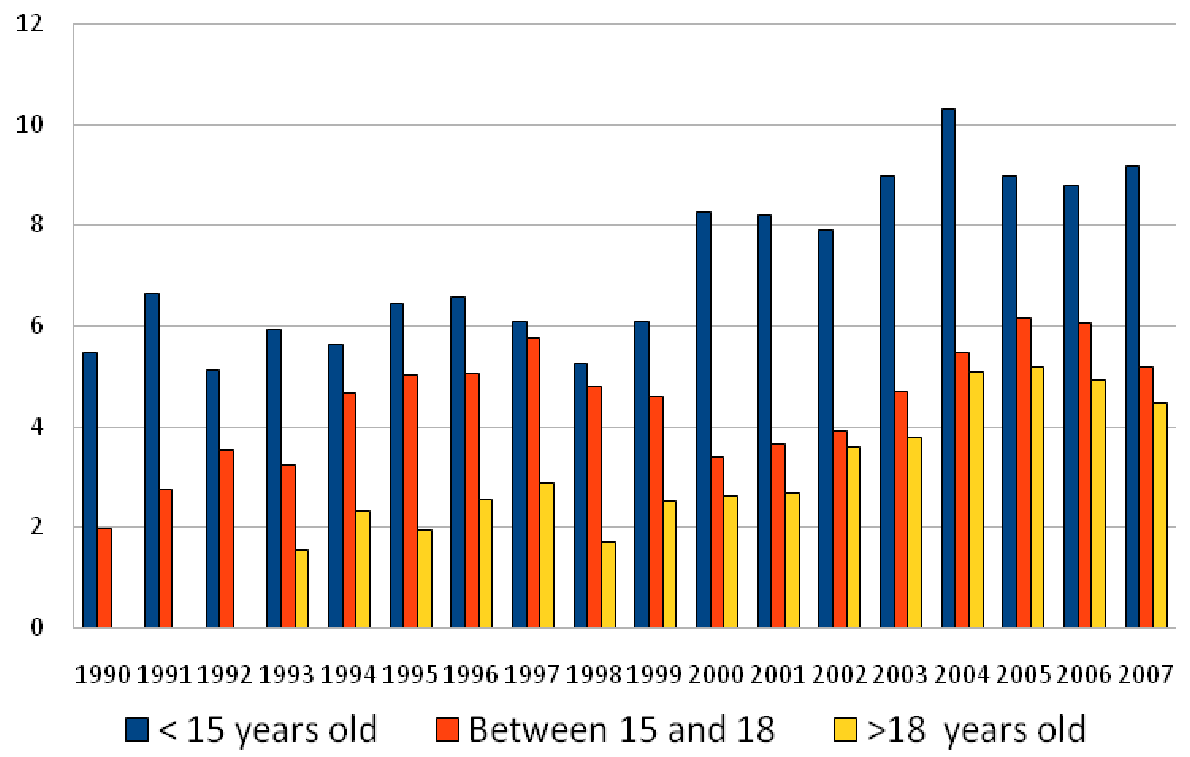


Figure 10: mean OVs and \% maximizing NPVs of retiring at each age

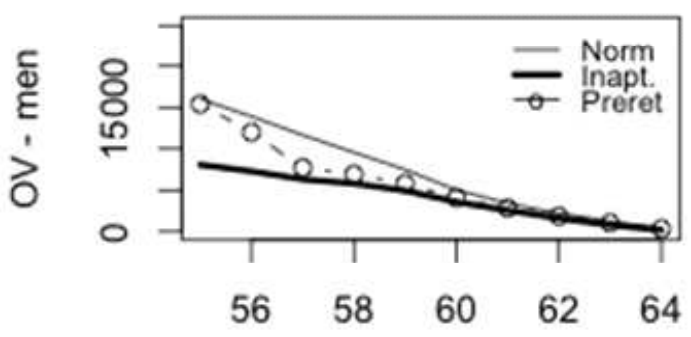

age

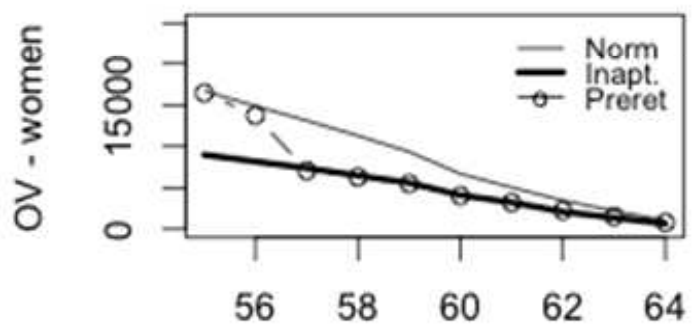

age

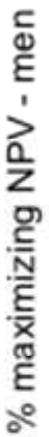

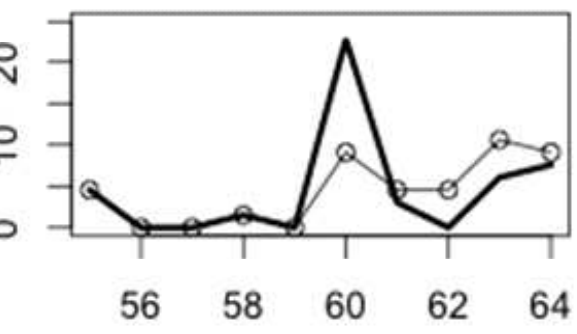

age

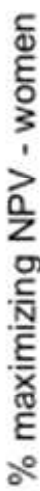

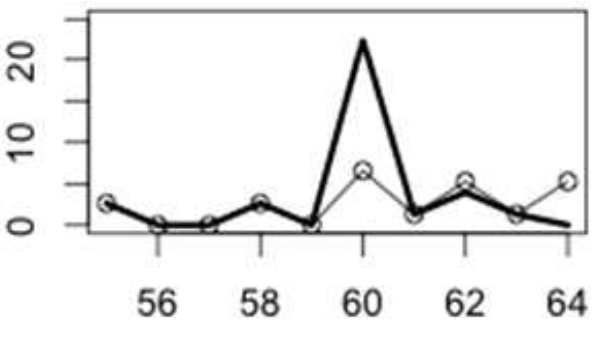

age 
Figure 11a: Percentiles of Health Index, by Age, Men

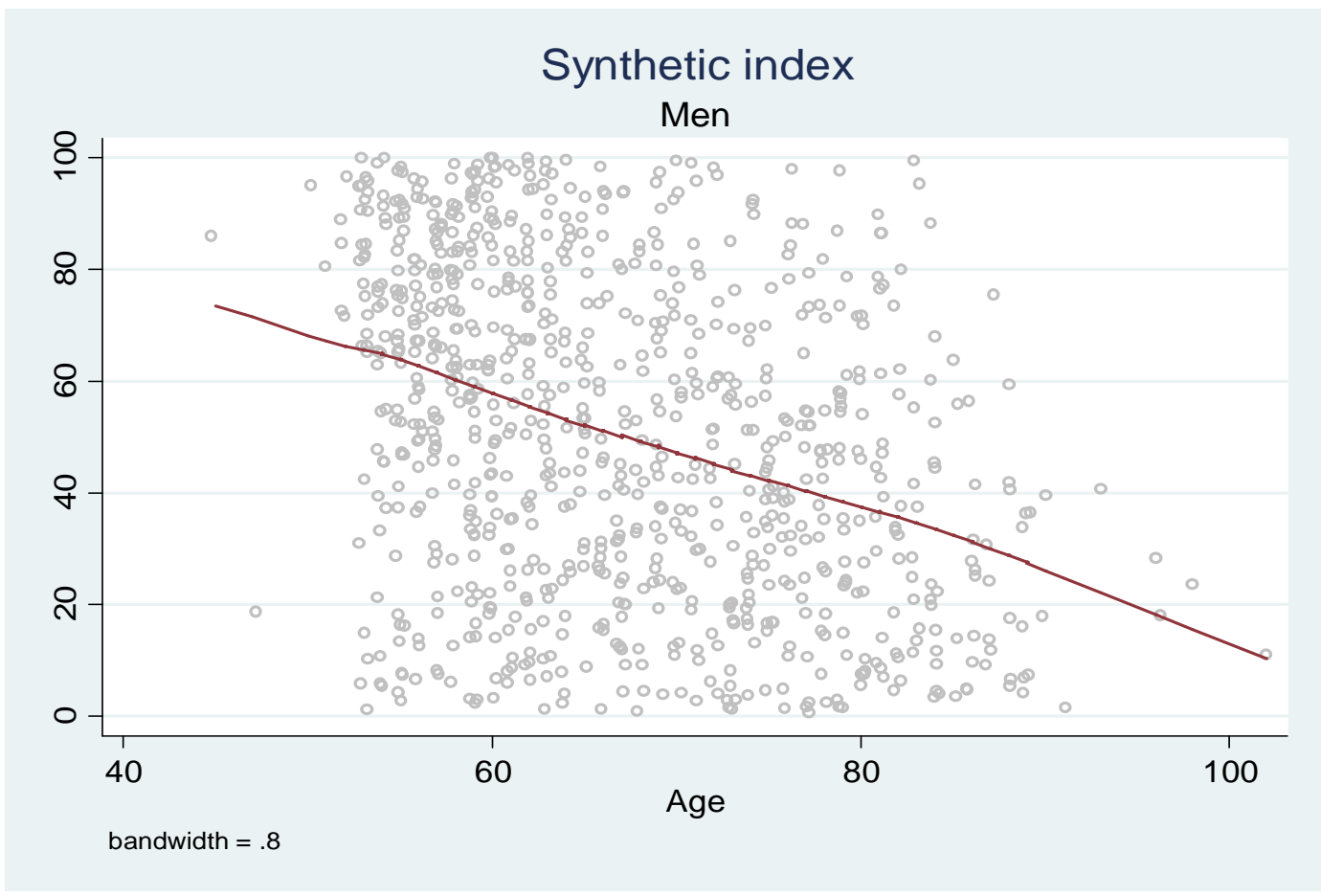

Figure $11 b$ : Percentiles of Health Index, byAge, Women

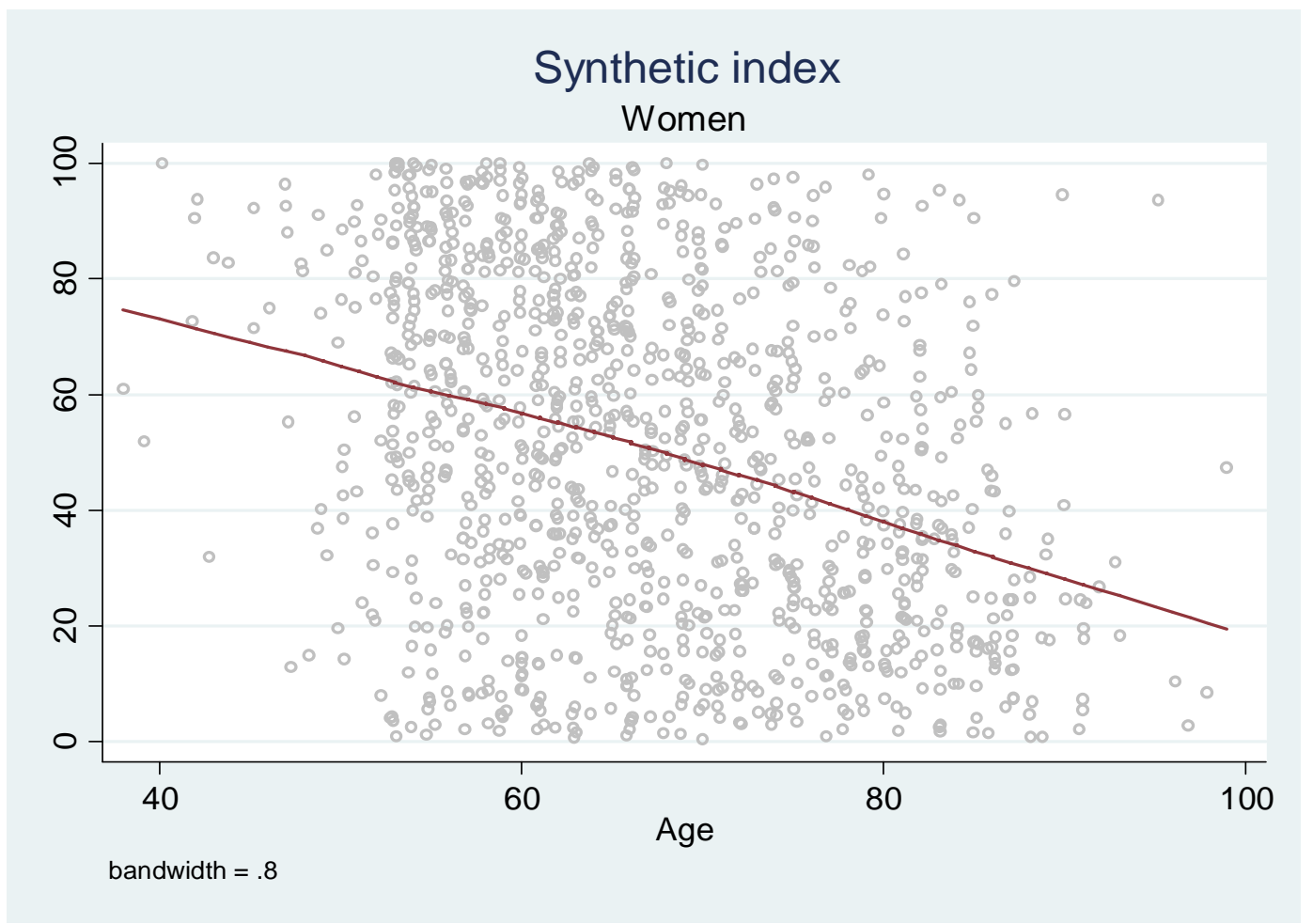


Figure 12a: Model Fit, Hazard, Men

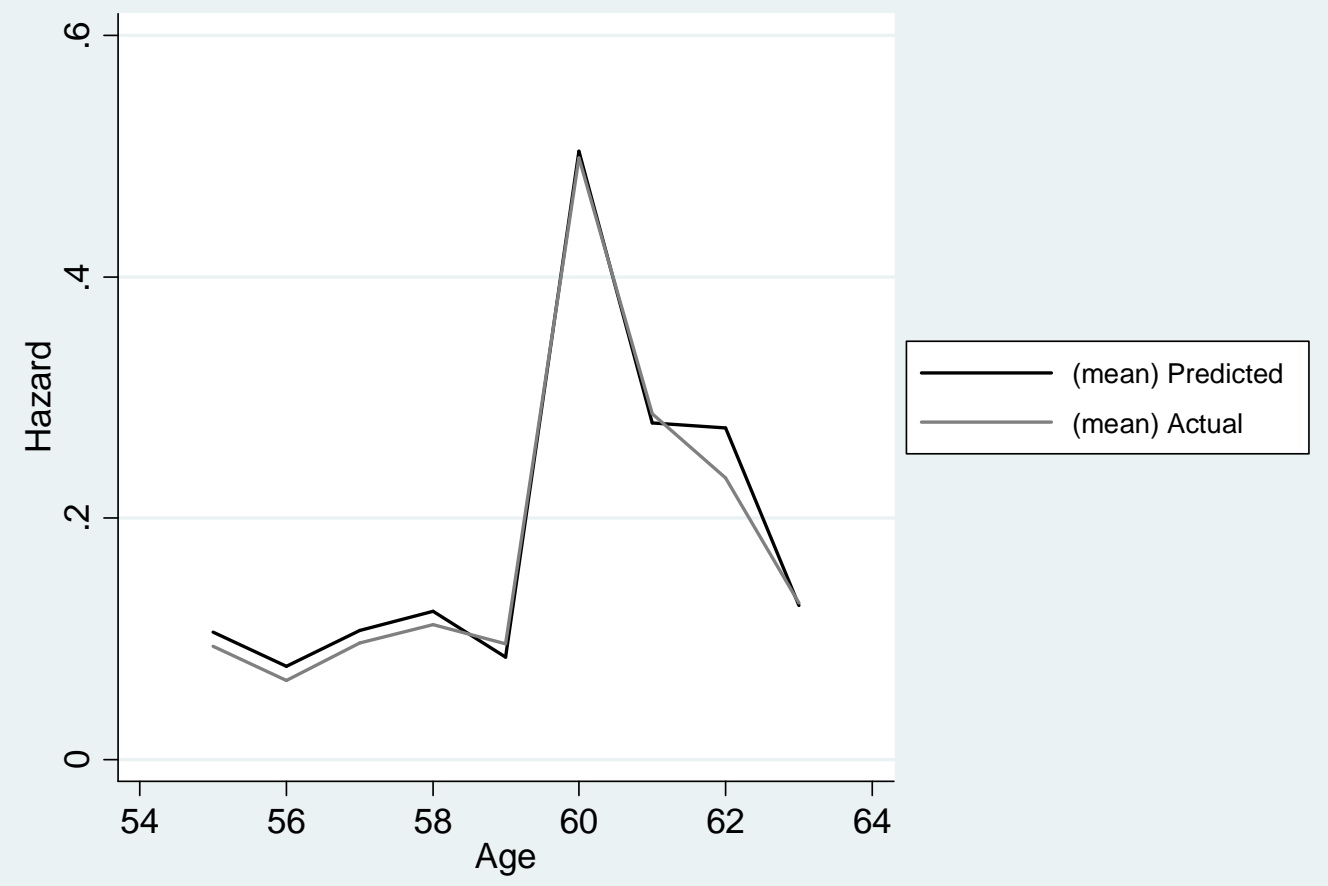

Figure 12b: Model Fit, Hazard, Women

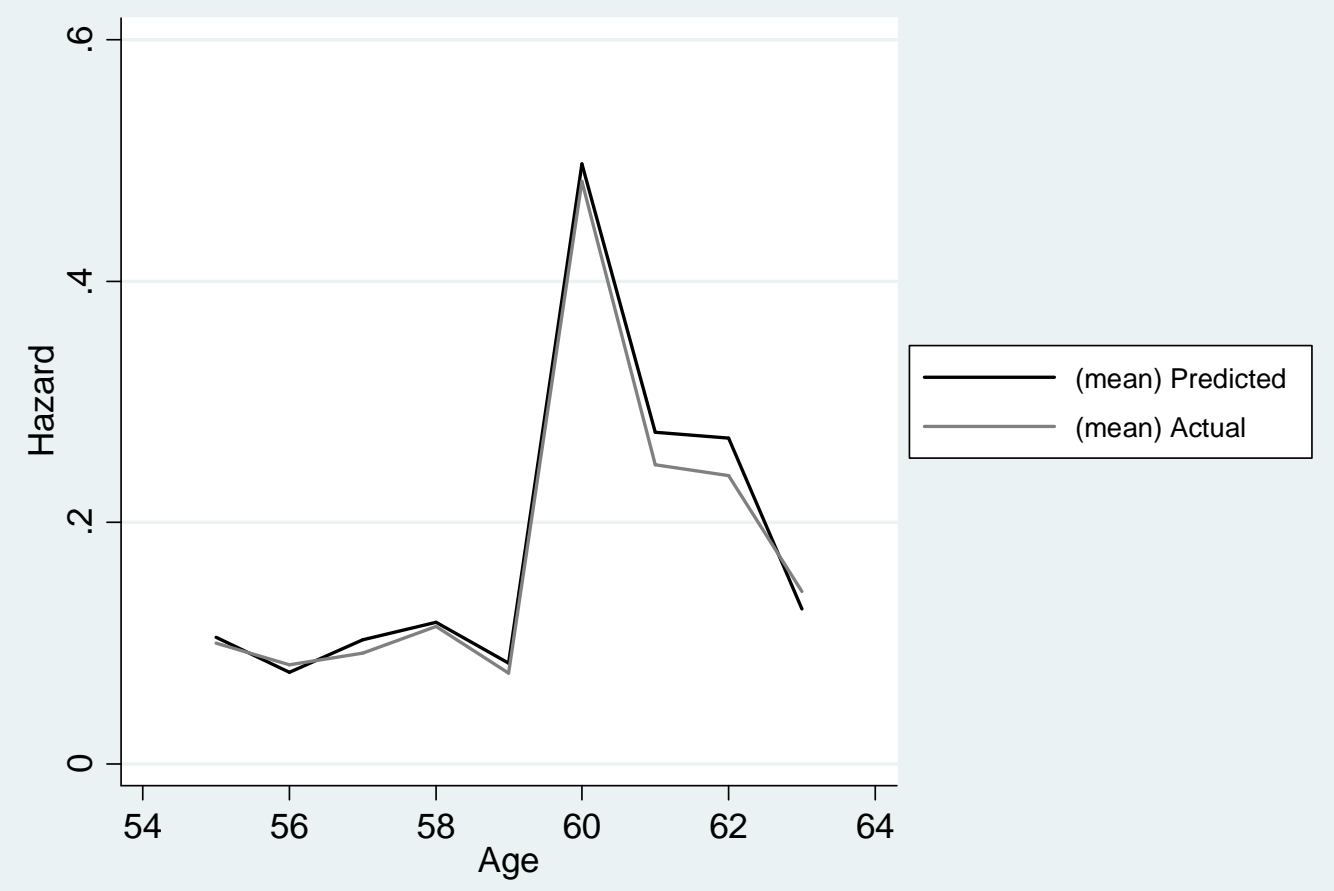


Figure 13a: Model Fit, Survival, Men

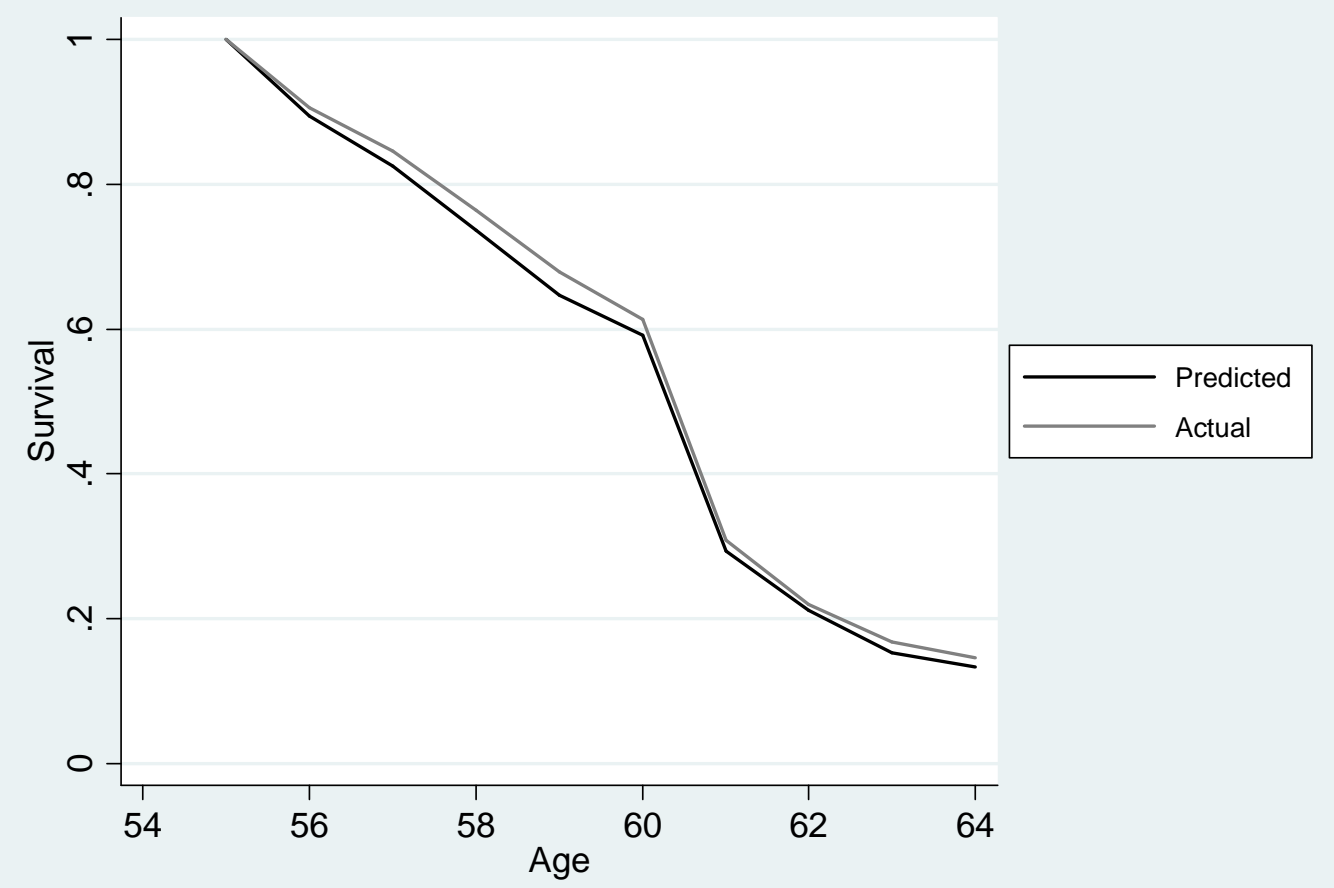

Figure 13b: Model Fit, Survival, Women

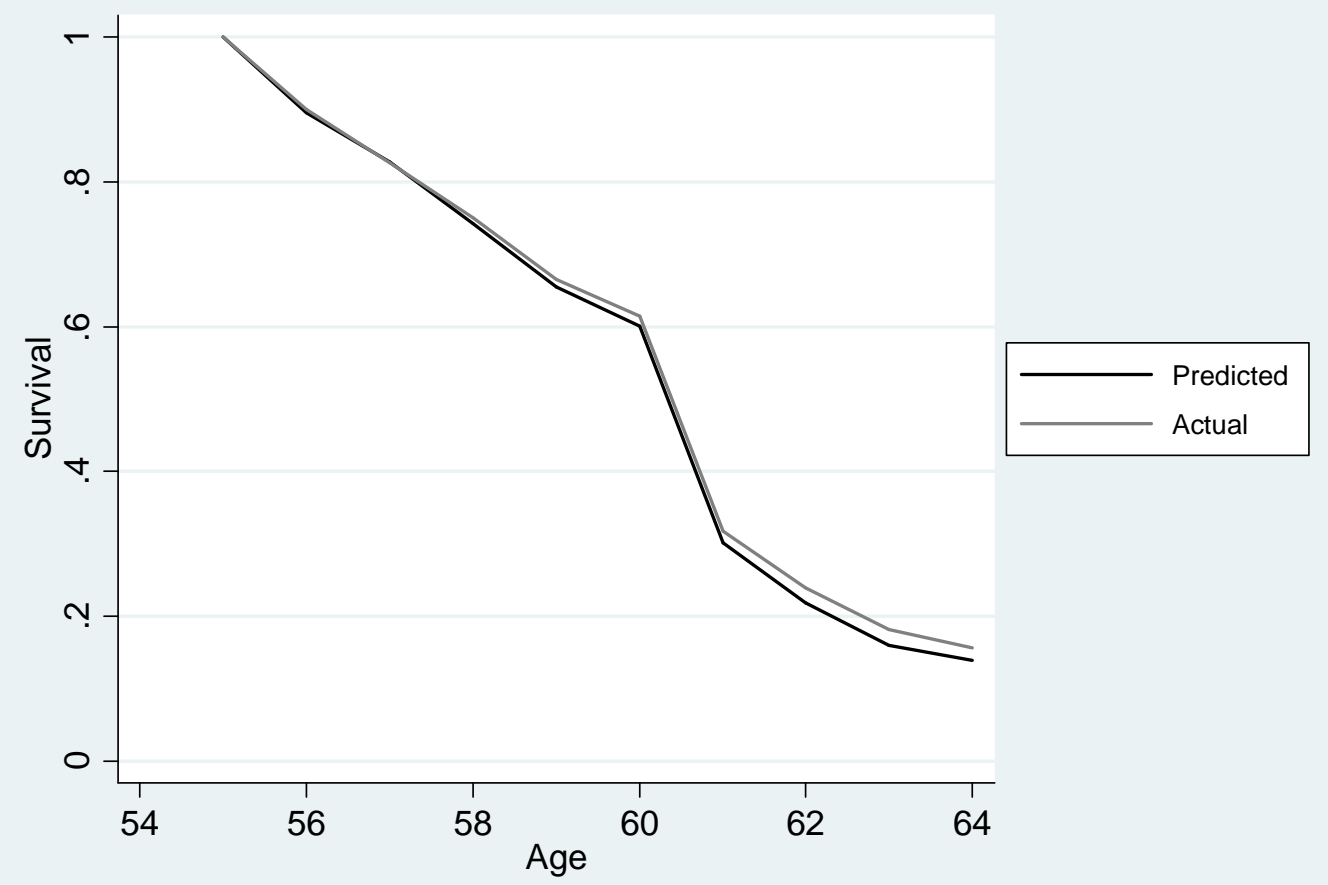


Figure 14: Predicted hazard, by health quintiles

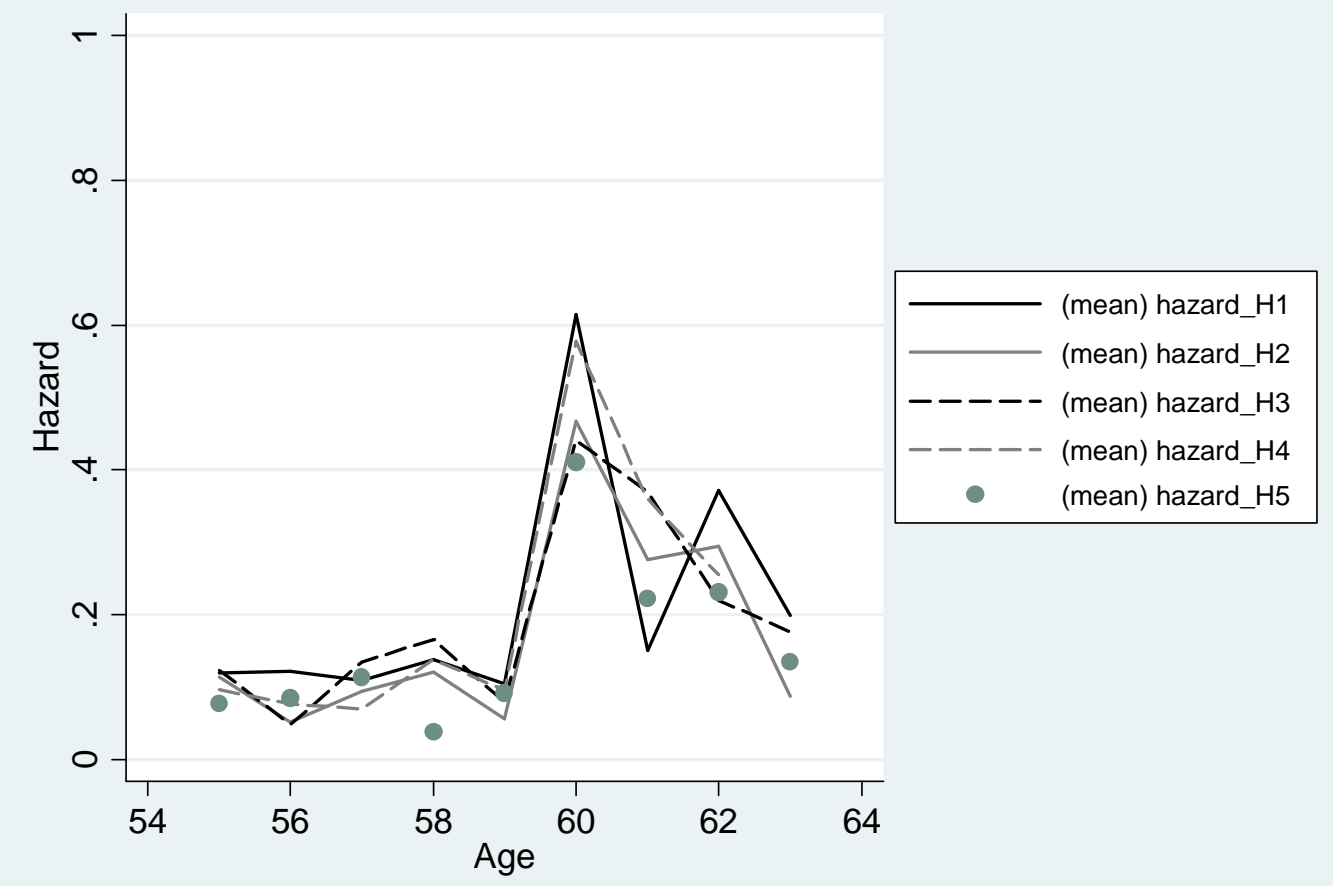


Figure 15: Survival functions under alternative scenarios, full sample

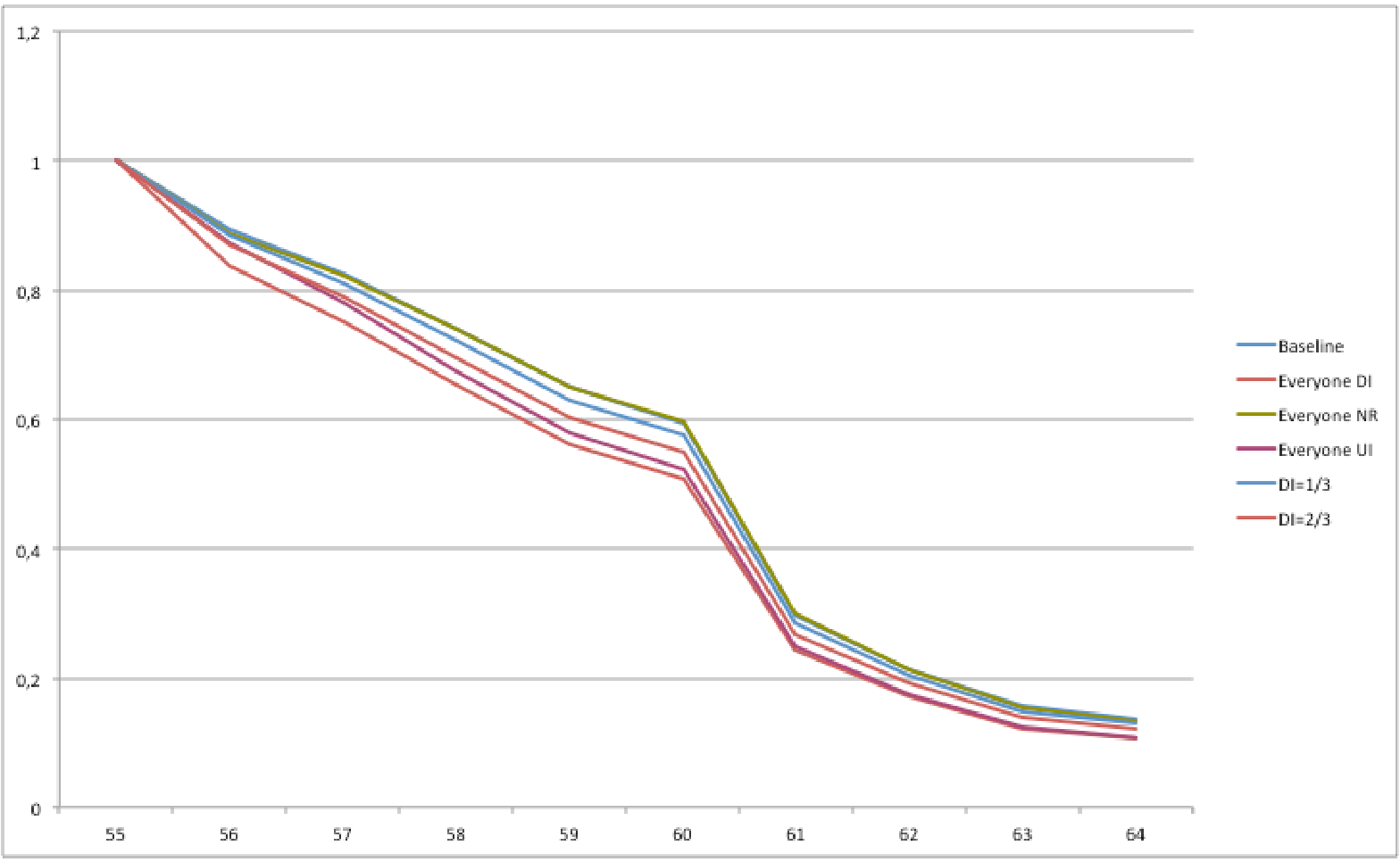

Figure 16: Survival functions under alternative scenarios, "DI" sample

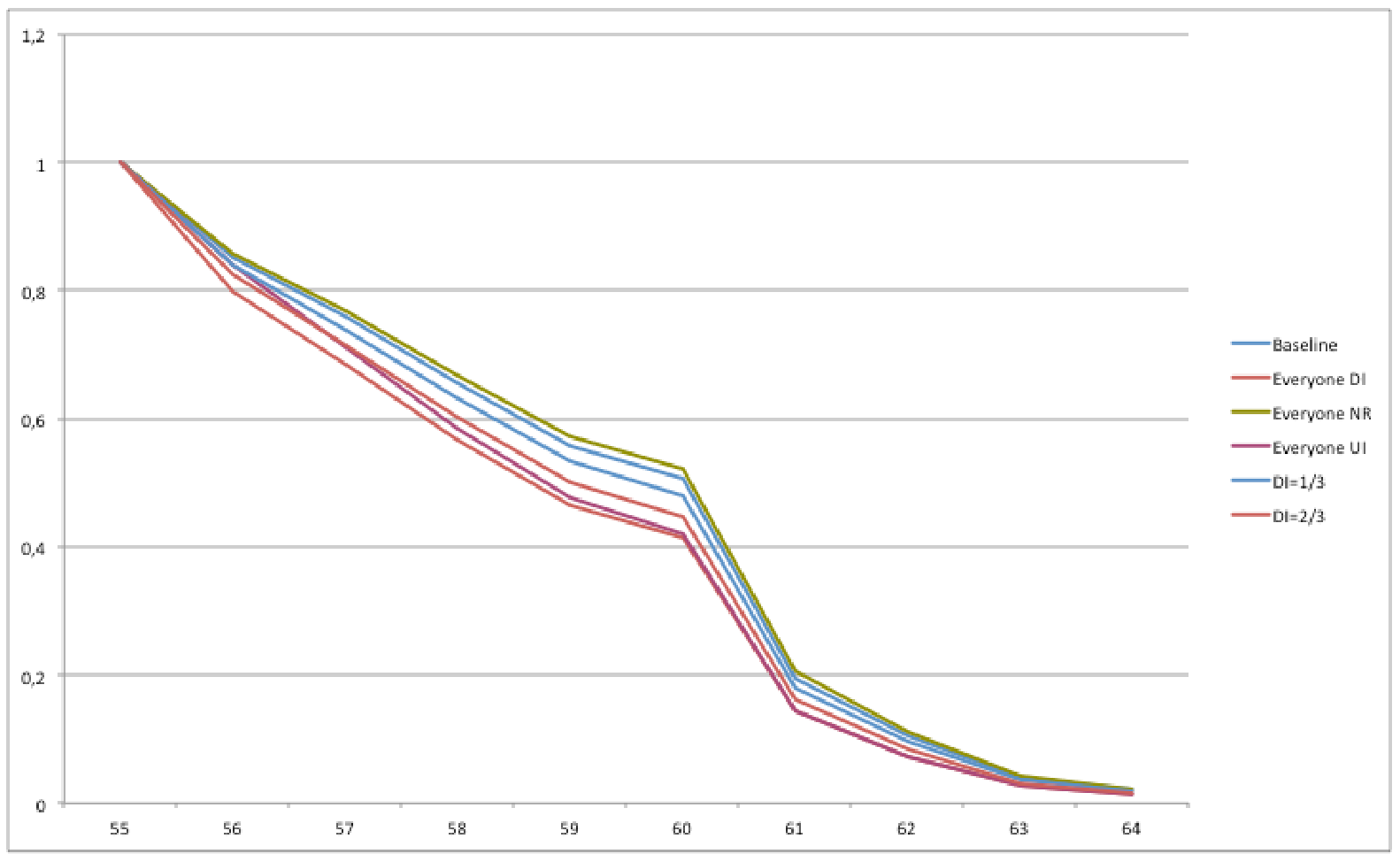

